\title{
Sıcaklık Kavramının Ölçümü Üzerinden Sorgulanması: Karşılaştırmalı Bir Araştırma ${ }^{1}$
}

\section{Inquiry the Temperature Concept via Its Measurement: A Comparative Study}

\author{
Yusuf Karademir, Muğla Merkez IMKB Ortaokulu, ykarademir70@hotmail.com \\ Ayșe Oğuz Ünver, Muğla Sitkı Koçman Üniversitesi, ayseoguz@mu.edu.tr
}

Öz. Bu çalışmada sıcaklık, ısı kavramından bağımsız ve moleküler düzeye inilmeden, nasıl ölçülebildiğinden yola çıkılarak tanımlanmaktadır. Çünkü sıcaklık maddenin fiziksel durumuna bağlı bir özelliktir. Çalışmada, öncelikle ortaokul öğrencilerinin ( $\mathrm{N}=109)$ ve fen bilimleri öğretmen adaylarının $(\mathrm{N}=77)$ sıcaklık kavramına ait ön bilgilerinin ortaya çıkarılarak sorgulanması ve karşılaştırması amaçlanmıştır. Daha sonra sorgulamaya dayalı verilen eğitimin ardından gönüllü katılımcılar, farklı sıcaklık parametrelerini dikkate alarak termometreler tasarlamışlardır. Eylem araştırması türünde desenlenmiş çalışmada, tasarlanan ürünler araştırmacılar tarafından geliştirilen ürün değerlendirme formu ile karşılaştırmalı çözümlenmiştir. Araştırmada ilginç olarak öğretmen adaylarının termometrenin kullanımı, hava sıcaklığının ölçümü ve termometrenin yapısı temalarında, ortaokul öğrencilerine göre daha çok çeliş̧iye düştükleri gözlenmiştir. Tasarlanan termometreler değerlendirildiğinde de, ortaokul öğrencilerinin, öğretmen adaylarına göre daha yaratıcı oldukları söylenebilir. Genel sonuç olarak katılımcılar, çalışma sonunda sıvıların genleşme özelliğinden yararlanılarak sıvllı termometrelerin çalışma prensibini, sıcaklık ölçümünü ve sıcaklık kavramının maddenin makroskobik (gözle görülebilen) özelliklerini değiștirdiğini keșfederler.

Anahtar Sözcükler: Sıcaklık, termometre, sorgulama temelli bilim eğitimi (stbe), ortaokul öğrencileri, fen bilimleri öğretmen adayları

\begin{abstract}
This paper defines temperature, unconnected from heat concept and without delving into the molecular level, from the starting point of how it can be measured. This is because temperature is a property of matter that depends on its physical state. Particularly the aim of the study was to inquiry and compare the middle school students' $(\mathrm{N}=109)$ and pre-service science teachers' $(\mathrm{N}=77)$ prior knowledge of temperature. Next, after the inquiry-oriented implementation volunteer participants designed thermometers by using different parameters. In the action research design study, created temperatures analyzed by the products evaluation form that was developed by the researcher. Interestingly, it was found that the pre-service teachers run into a contradiction when compared with the middle school students about the use of thermometers, measuring the air temperature and the structure of the thermometers. When evaluated the designed thermometers, it can be said that middle school students were more creative than the pre-service teachers were. Overall results of the study, the participants discovered liquid thermometers work with the help of the expansion property of liquids; temperature measurement and how temperature changes the macroscopic (visible) properties of matter.
\end{abstract}

Keywords: Temperature, thermometer, inquiry based science education (lbse), middle school students, pre-service science teachers

\footnotetext{
${ }^{1}$ Bu araştırmanın bir bölümü XI. Ulusal Fen Bilimleri ve Matematik Kongresinde sözlü bildiri olarak sunulmuştur ve Bu makale yazar Yusuf Karademir'in Muğla Sıtkı Koçman Üniversitesi Eğitim Bilimleri Enstitüsü’nde 2016 yılında tamamlanan "Sıcaklık ölçümünden yola çıkarak sıcaklık kavramının sorgulanması" başlıklı yüksek lisans tezinden yararlanılarak hazırlanmış̧ır.
} 


\section{Introduction}

\section{SUMMARY}

In a simple experiment carried out by John Locke in 1690, it was observed that defining temperature was more of a relative endeavor than it seemed at first. In the experiment, we put one of our hands in warm, the other in cold water, wait for a little while and then take both hands out and put them in water at room temperature. The result is that one of our hands feels warm in the same water while the other feels cold. Even this experiment is enough to show that depending on our senses to define temperature may be misleading. There is a need for a scientific, objective and quantitative measurement of temperature. The literature reveals different definitions of temperature. In some studies, temperature is defined as the magnitude of heat flow while others generally define it as the average kinetic energy of molecules. Such a definition may be useful but it is not always valid since the molecular activity in water and steel at the same temperature, for instance, are not equal.

Another aspect that is confusing about temperature is that while heat is a type of energy, temperature is not. In most textbooks, the topics of heat and temperature are treated together. When the literature is reviewed, it is seen that heat and temperature are treated together despite the fact that they are two separate concepts and the large majority of current studies deal with the subject of students' misconceptions. So what is this concept of temperature that occupies our minds so much? How can it be taught? This paper defines temperature, unconnected from heat concept and without delving into the molecular level, from the starting point of how it can be measured. This is because temperature is a property of matter that depends on its physical state.

\section{Method}

Particularly the aim of the study was to inquiry and compare the middle school students' $(\mathrm{N}=109)$ and pre-service science teachers' $(\mathrm{N}=77)$ prior knowledge of temperature. Next, after the inquiry-oriented implementation volunteer participants designed thermometers by using different parameters All thermometers make use of the principle that some physical parameters change with heat. These parameters are (1) the change in the volume of liquids, (2) the change in the length of solids, (3) the change in the pressure of a gas in a fixed volume, (4) the change in the volume of a gas at fixed pressure, (5) the change in the electrical resistance of a conductor, (6) the change in their color. In the action research design study, the created temperatures analyzed by the products evaluation form that was developed by the researcher. The thermometers evaluated in terms of the following codes (1) How close were the created thermometers to the real ones? (2) On which parameters the thermometers were designed? (3) Which states of matters the thermometers are measuring? (4) How is the thermometers design and functionality?

\section{Results}

Interestingly, it was observed that the pre-service teachers run into a contradiction when compared with the middle school students about the use of thermometers, measuring the air temperature and the structure of the thermometers. When evaluated the designed thermometers, it can be said that middle school students were more creative than the preservice teachers were. Overall results of the study, the participants discovered liquid thermometers work with the help of the expansion property of liquids; temperature measurement and how temperature changes the macroscopic (visible) properties of matter.

\section{Discussion and Conclusion}

Students' contradictions on the concept of the temperature may have its roots from their prior knowledge of temperature, heat, energy and gravity (Karakuyu, 2006; Çekiç, 2004). Transforming the learned knowledge into a product provides students a better understanding and questioning of the concepts (Dorris, 1991; Yağbasan ve Gülçiçek, 2003; Ateș, 2005). It also provides not only focusing the outcome but also focusing on the process-oriented assessment 
during the elimination of the misconceptions. Since children are tended to inquiry because of their nature, they may be more imaginative than the adults may. Previous knowledge and experience of adults involved in the teaching process could block their creativity (Duban, 2008; Yürümezoğlu ve Oğuz, 2009).

The key pedagogical approaches taken in this study is to develop students' observation skills during inquiry. Students observe phenomenon in connection with prior experiences and the structure of observed phenomenon (Laçin-Şimşek ve Tezcan, 2008). One of the main principles of teacher's questioning is to make the students' inner questions based on the provoked curiosity visible.

Current study address not only the content knowledge of temperature, but also numerous science standards asking questions (for science) and defining problems (for engineering); planning and carrying out investigations; analyzing and interpreting data; using mathematics and computational thinking; constructing explanations (for science) and designing solutions (for engineering); engaging in argument from evidence; obtaining, evaluating, and communicating information.

\section{GíRIş}

Tanımı konusunda bir uzlaşı sağlanamamıș terimleri okul ders kitaplarında tanımlamaya çalışmak hata yapmamıza neden olur. Örneğin, John Locke tarafından 1690 yılında gerçekleştirilen basit deneyde; sıcaklığı tanımlamanın göründüğünden daha göreceli olduğu gözlenir. John Locke tarafından gerçekleștirilen deneyde; bir elimizi sıcak, diğer elimizi soğuk suya sokup bir süre bekledikten sonra her iki elimiz de orta sıcaklıkta bir suya sokulur. Sonuçta, aynı suyu bir elimiz sıcak hissederken diğer elimiz soğuk hissedecektir. Sadece bu deney bile sıcaklığı, duyularımızla tanımlamaya çalışmanın yanıltıcı olabildiğini göstermektedir. Konunun bir diğer boyutu ise, duyularımız yardımı ile belirleyeceğimiz sıcaklıkların sınırlı olabileceğidir. Zira her canlının sıcaklığa dayanabileceği belli bir aralık vardır. Bu yüzden bilimsel olarak, objektif ve sayısal bir sıcaklık ölçeğine gerek duyulmaktadır.

Sıcaklık, bazı çalışmalarda ısının akış yönünü gösteren bir büyüklük olarak yer alırken (örn., Milli Eğitim Bakanlığı [MEB], 2014a) çoğu zaman "Moleküllerin ortalama kinetik enerjisi ...” şeklinde tanımlanır (örn., Challoner, 2005; Challoner, 2006; Çepni, Ayvacı ve Çil, 2012; Bolat, Aydoğdu ve Evgi, 2013; Bayram ve Kibar, 2014; Kurnaz ve diğerleri, 2014; Milli Eğitim Bakanlı̆̆ [MEB], 2014b; Öcal, 2014; Ünver, 2014). Genel olarak değerlendirildiğinde böyle bir tanım yararlı olabilir; ancak her zaman geçerli değildir, çünkü aynı sıcaklıktaki su ve çeliğin moleküler aktiviteleri eşit değildir (Jones ve Dugan, 2003). Zira verilen örneklerde (Çepni, Ayvacı ve Çil, 2012) kütleleri farklı aynı tür maddelerin aldıkları ısı miktarlarından dolayı eşit sıcaklıkta olduğu tanımı geçerli olabilir. Oda sıcaklığında veya aynı ortamda bir bardak su ile bir kova suyun sıcaklıklarının eşit olması bu duruma örnektir. Buradaki aynı tür maddelerin moleküllerinin ortalama kinetik enerjileri eșittir.

Sıcaklık kavramının tanımının çeşitlilik göstermesinin yanında, kavramın öğrenenlere aktarımında da bir uzlaşı yoktur. Okul ders kitaplarının çoğunda ısı ve sıcaklık konularının öğretimi birlikte ele alınır (örn., Çepni, Ayvacı ve Çil, 2012; Bolat, Aydoğdu ve Evgi, 2013; Agalday, Akçam, İpek ve Kablan, 2014; Bayram ve Kibar, 2014; Keskin-Özer, Kaşker-Özkan ve Uysal, 2014; Kurnaz ve diğerleri, 2014; MEB, 2014a; MEB, 2014b; Öcal, 2014; Ünver, 2014). Diğer taraftan fizik ve mühendislik alanındaki kitaplara bakıldığında isı ve sıcaklığın ayrı başlıklar altında ele alındığı; sıcaklığın, termodinamiğin sıfırıncı kanunu başlığı altında işlerken; ısının enerji başlığı altında incelendiği görülmektedir (örn.,Serway, 1995; Halliday ve Resncick, 1997).

Sıcaklık konusunda kafalardaki en çelişkili bir başka durum da, ısının bir enerji olduğu ancak sıcaklığın bir enerji olmadığıdır. Sıcaklığın tanımında; "sıcaklık bir maddenin moleküllerinin ortalama kinetik enerjisi..." (Ünver, 2014; 153), "Madde içinde dönme titreşim veya öteleme hareketi yapan atom ya da moleküllerin ortalama kinetik enerjisinin bir göstergesidir" (MEB, 2014b), "Sicaklık, bir molekülün ya da atomun ortalama kinetik enerjisiyle 
orantılı bir büyüklüktür"(Kurnaz ve diğerleri, 2014; 51), "Bir maddenin sıcaklığı o maddeyi oluşturan parçacıkların ortalama kinetik enerjisi ile ilgilidir" (Challoner, 2005; 22), "Bir maddenin sıcaklığı, o maddeyi oluşturan parçacıkların içerdiği ortalama ısı (ya da kinetik) değeridir..." (Challoner, 2006; 28) ve "Maddenin taneciklerinin ortalama kinetik enerjisi ise sıcaklıktır." (Çepni, Ayvacı ve Çil, 2012; 232) şeklinde ifadeler yer almaktadır. Burada ise sıcaklık, enerji ile birlikte anılmaktadır. Tanımlamalarda sıcaklığın bir enerji olduğu yanılgısına düşülebilir. Buraya kadar sıcaklık kavramına ilişkin alışıla gelmiş, bildiğimiz ancak sorgulandığında zihnimizde bir takım çelişkiler yaratan durumlar sıralanmıştır.

Genellikle sıcaklık kavramına ilişkin açıklamalar ısı kavramı ile benzerliği ve farklılığı üzerine kurgulanmış ya da modeller kullanılmıştır. Young, Freedman ve Ford, (2008) sıcaklığın nasıl ölçülebildiğinden yola çıkarak sıcaklık kavramının tanımlanabileceği; bunun için de sıcaklığın, cisimlerin boyutlarını nasıl etkilediği üzerinde durulması gerektiğini vurgulamışlardır. Sıcaklık, maddeye ait moleküllerin kinetik enerjisine bağlı olması; bu kavramı ısı ile karmaşık bir ilişki içerisine sokmaktadır. Bu yüzden sıcaklığı açıklamak için iyi bir giriş olmayacaktır. Sıcaklık ve ısı moleküler düzeye inilmeden de tanımlanabilir. Çünkü sıcaklık maddenin fiziksel durumuna bağlıdır.

\section{Sicaklık}

Sıcaklık kavramı çok sık kullanmamıza rağmen temel fen eğitimi alan herkesin rahatlıkla tanımlayabileceği bir kavram olmayabilir. Black'ın Fahrenheit termometresiyle yaptığı deneyler sonundaki ilk ve temel keşfi, ısı ile sıcaklık derecesinin aynı olmadığıdır. 20. yüzyıl gözü ile bakılınca, bu keşifte pek öyle dünyayı sarsan taraf görülmese de, Black'ın çağdaşlarından hiçbir bilim insanın ısı ile sıcaklık arasındaki kesin farkı ortaya koymaya gücünün yetmediği bir gerçektir (McCue, Gossner, Loomis, McDonald ve Osmundsen; 1970). Bu yüzden sıcaklık kavramını tanımlama yeni sayılabilir.

Türk Dil Kurumu'nun sözlüklerinde sıcaklık farklı tanımlanmaktadır. Örneğin Güzel Sanatlar Terimleri Sözlüğü'nde sıcaklık kelimesini "hamamlarda yıkanılan sıcak yer" şeklinde ifade ederken Fizik terimleri sözlüğünde "bir isıl ölçerle ölçülen ısıl yeğinlik" olarak ifade edilmiştir. Türk Dil Kurumu'nun diğer tanımları ise: Isıl devingen dengedeki bir özdeğin, her bir özdeciği başına düşen ortalama devinim erkesini ölçen nicelik". Üniversitelerin fen ve mühendislik fakültelerinde okutulan bazı kitaplarda yer alan sıcaklık tanımlarında; "Bir sistemin ortalama moleküler kinetik enerjisinin bir ölçüsüdür"(Çengel ve Boles, 2008). Sears ve Salinger, (2002) göre bütün olağan cisimlerin başka cisimlerle temas ettiklerinde isıl dengeye erişip erişmeyeceklerine karar veren fiziksel özellik olarak sıcaklığı tanımlarken; Jones ve Dugan (2003), sıcaklığı termodinamiğin sıfırıncı yasası ile tanımlanır. Bu tanım, birbiriyle temasta bulunan sayısız sistem (nesne) bir dengeye erişinceye dek ısı alış verişinde bulunur. Bu dengeye ulaşıldığı anda stabilize olmuş nicelik sıcaklıktır.

Bir diğer tanım ise;

"Sıcaklığı tanımlayabilmek için önce termal temas ve termal denge tanımlanmalıdır. İki cisim birbirleri üzerinde makroskobik iş yapmadan enerji değiş tokuşu yapıyorlarsa bu iki cisim Termal Temas'tadır. Termal temasta olan sıcaklıkları farklı iki cisim arasında net enerji alış verişi sona ermiş ise, bu iki cisim Termal Denge'dedir. Termal Temasta olmayan A ve B gibi iki cisim üçüncü bir C cismi ile ayrı ayrı termal dengede ise o zaman A ve B cisimleri birbirleri ile termal dengededir. $\mathrm{Bu}$ duruma termodinamiğin sıfırıncı kanunu (denge kanunu) olarak adlandırılır. $\mathrm{Bu}$ ifade sıcaklığı tarif etmek için kullanılmaktadır. Bir başka değişle sıcaklık bir cismin bir başka cisimle termal dengede olup olmadığını belirleyen bir özelliktir" Serway, (1995).

Bir cismin termal dengede olup olmadığını tespit etmek için; cisim üzerindeki sıcaklık etkisi ile değişen makroskobik değişimlerden yararlanan termometreler geliştirilmiştir. Bilinen ilk sıcaklık değişimlerini gösteren termoskobu, 1593 yılında Galileo yapmıştır. Galileo'nun ölçme cihazı hakkındaki Diyalog isimli eserinde geçen altı, dokuz, on sıcaklık derecesi deyimlerinden başka pek birşey bilinmemekteydi. Ancak diğer araştırmacılara ilham olduğu da bir gerçektir. Fahrenheit, temeli Galileo'nun Termoskop'una dayanan Amontons'un geliştirdiği cihazı mükemmelleştirerek; insanoğlunun güvenebileceği termometreyi yaptı. Bu dönemden sonra 
insanoğlu sıcaklık ölçümü için kendi duyularının dişına çıkarak termometreyi kullanmışlardır (McCue vd., 1970). Günümüzde termometreleri, sıcaklık etkisinde değișen makroskobik değerlerin ölçümünden yararlanırlar. Serway (1995) göre bütün termometreler bazı fiziksel parametrelerin sıcaklıkla değișmesi prensibini kullanırlar. Bunlar:

1. Sıvıların hacimlerinin değişmesi,

2. Katıların uzunluğunun değişmesi,

3. Sabit hacimdeki bir gazın basıncının değişmesi,

4. Sabit basınçtaki bir gazın hacminin değişmesi,

5. Bir iletkenin elektrik direncinin değişmesi,

6. Çok sıcak cisimlerin renk değişimi şeklinde fiziksel özelliklerin değişmesi durumunda sıcaklıklarının ölçümü yapılmaktadır.

Sonuç olarak, madde üzerindeki makroskobik değişimdeki nesnel niceliği kullanarak sıcaklığı sayısal değerlere çeviren araçlara termometre denir. Termometre ile bilimsel olarak, objektif ve sayısal bir sıcaklık ölçeğine ulaşılmıștır. Günümüzde sıcaklığın fiziksel parametrelerinden yola çıkarak farklı türde termometreler geliştirilmektedir. Örneğin sıvıların genleşme özelliğinden yararlanılarak sıvilı termometreler ya da metallerin genleşme özelliğinden yararlanılarak metal termometreler geliştirilmiştir.

\section{Sıcaklık Kavramı ile İlgili Çalıșmalar}

Literatüre bakıldığında ısı ve sıcaklık kavramları birlikte ele alınmış ve neredeyse mevcut araştırmaların büyük çoğunluğu durum çalışması olup, öğrencilerdeki kavram yanılgıları üzerine yoğunlaşmıştır. Örneğin ilkokul düzeyinde (örn., Erickson, 1979; Tiberghien, 2000; Buluş Kırıkkaya ve Güllü, 2008; Gürdal, 2008; Bayram, 2010), 6., 7. ve 8. sinıf düzeyinde (örn., Erickson, 1979; Thomaz, Malaquias, Valentean ve Antunes, 1995; Kalem ve Çallıca, 2001; Mert, 2002; Yumuşak, Türkoğuz, Aycan ve Aycan, 2004; Başer ve Çataloğlu, 2005; Aydın, 2007; Gürbüz, 2008; Sarı-Ay, 2011; Turgut ve Gürbüz, 2011), lise düzeyinde (örn., Jara-Guerrero, 1993; Kesidou ve Duit, 1993; Eryılmaz ve Sürmeli, 2002; Kocakülah ve Kocakülah, 2002; Aydoğan, Güneş ve Gülçiçek, 2003; İnal, 2003; Güler, 2005; Yılmaz, 2005; Karakuyu, 2006; Yeşilyurt, 2006; Keser, 2007; Karakuyu, Uzunkavak, Tortop, Bezir ve Özek, 2008) ve öğretmen adayları ile yürütülen araştırmalarda (örn., Kaptan ve Korkmaz, 2001; Aydoğan, Güneş ve Gülçiçek, 2003; Demirci, 2003; Gümüş, Öner, Kara, Orbay ve Yaman, 2003; Demirci ve Sarıkaya, 2004; Gönen ve Akgün, 2005; Ongun, 2006; Damlı, 2011; Yavuz ve Büyükekşi, 2011; Taşlıdere, Korur ve Eryılmaz, 2012; Öner- Sünkür, İlhan ve Sünkür, 2013; Uzoğlu ve Gürbüz, 2013) ısı ve sıcaklık kavramlarına ilişkin benzer kavram yanılgılarına rastlanılmıştır. Bu kavram yanılgılarından öne çıkanlar Tablo 1'de sunulmuştur.

Sıcaklık kavramının öğretimi ile ilgili alan yazında birçok çalışma yapılmıştır. Bu çalışmalardan bazılarına yakından bakılacak olursa, örneğin, Demirci (2003), İnal (2003) ve Yılmaz'ın (2005) çalışmalarında, kavram yanılgılarının giderilmesinde yapılandırmacı yaklaşım ile geleneksel öğretim yaklaşımı arasında yapılandırmacı yaklaşım lehine istatistiksel olarak anlamlı fark olduğu, Başer ve Çataloğlu (2005) tarafından gerçekleştirilen çalışmada ise, kavram değişimi yöntemine dayalı öğretimin kavram yanılgılarını azaltmada geleneksel yaklaşıma göre daha etkili olduğu tespit edilmiştir. Gönen ve Akgün (2005) çalışmasında, elde edilen bulgular doğrultusunda sınıf içi tartışma yönteminin bilgi eksikliklerini gidermede etkili ancak kavram yanılgılarını gidermede etkili olmadığı ifade edilmiștir. Aydın (2007) çalışmasında, kavram haritası tekniğinin geleneksel yaklaşıma göre ısı ve sıcaklığa ilişkin kavram yanılgılarını giderebilmede daha etkili olduğunu tespit etmiștir. Gürbüz (2008) 'ün ve Sarı-Ay (2011) 'ın ısı ve sıcaklık konularındaki çalışmalarında, kavramsal değişim metinlerinin, geleneksel yaklaşıma göre kavram yanılgılarını azaltmada istatistiksel olarak anlamlı fark yarattığ konulmuştur. Bayram (2010) çalışmasında, Probleme Dayalı Öğrenme yönteminin, geleneksel öğrenme yöntemlerine göre öğrencilerdeki ısı ve sıcaklık konusundaki kavram yanılgılarını gidermede daha başarılı olduğu sonucuna ulaşmıştır. 
Tablo 1. Kavram yanılgıları

\begin{tabular}{|c|c|}
\hline Kavram Yanılgısı & Literatür \\
\hline Sıcaklık değerinin sıfır olmasını ısının olmadı̆̆ı şeklinde düşünmektedirler. & Gürdal, (2008) \\
\hline Isıalan bir maddenin sıcaklığı kesinlikle değişir. & Bayram, (2010) \\
\hline Cisimlere verilen ısı miktarının cisimlerinin sıcaklığının artmasına etkisi olmadığını & Gürbüz, (2008) \\
\hline Aynı miktar ısı alan maddelerdeki sıcaklık artışı da aynıdır. & Keser, (2007) \\
\hline $\begin{array}{l}\text { Isı, sadece cisimlerin sıcaklığı ile artar veya azalır. } \\
\text { Isı ve sıcaklık maddeler için ayırt edici özelliktir. }\end{array}$ & Sarl-Ay, (2011) \\
\hline $\begin{array}{l}\text { Bir cismin sıcaklığı o cismin ısısından bağımsızdır. } \\
\text { Bir cismin diğer bir cisme göre sıcaklığı yüksekse her zaman ısısı da yüksektir. }\end{array}$ & $\begin{array}{l}\text { Aydoğan, Güneş ve Gülçiçek, } \\
\text { (2003); Aydın, (2007) }\end{array}$ \\
\hline $\begin{array}{l}\text { Eğer iki vücudun sıcaklıkları aynıysa onların ısıları veya enerjileri de ayıdır. } \\
\text { Sıcaklık ısının miktarıdır. } \\
\text { Isı yüksek sıcaklıktır. }\end{array}$ & Kesidou ve Duit, (1993) \\
\hline Isı ve sıcaklık aynı kavramlardır. & $\begin{array}{l}\text { Erickson, (1979); Thomaz, } \\
\text { Malaquias, Valente ve Antunes, } \\
\text { (1995); Kaptanve Korkmaz, } \\
\text { (2001); Eryılmaz ve Sürmeli, } \\
\text { (2002); Aydoğan, Güneş ve } \\
\text { Gülçiçek, (2003); Demirci, } \\
\text { (2003); Gümüş, Öner, Kara, } \\
\text { Orbay ve Yaman, (2003); İnal, } \\
\text { (2003); Bașer ve Çataloğlu, } \\
\text { (2005); Ongun, (2006); Aydın, } \\
\text { (2007); Keser, (2007); } \\
\text { Gürbüz, (2008); Bayram, } \\
\text { (2010); Sarı Ay, (2011);Yavuz, } \\
\text { ve Büyükekși, (2011) }\end{array}$ \\
\hline $\begin{array}{l}\text { Isı ve sıcaklığın farklı olduklarını söylemelerine rağmen, öğrenciler bunları } \\
\text { birbirlerinin yerine kullanması. }\end{array}$ & Jara-Guerrero, (1993) \\
\hline $\begin{array}{l}\text { Isı sıcaktır; fakat sıcaklık soğuk veya sıcak olabilir. } \\
\text { Isı ve sıcaklık arasında bir fark yoktur. }\end{array}$ & $\begin{array}{l}\text { Tiberghien, (2000); Başer ve } \\
\text { Çataloğlu, (2005) }\end{array}$ \\
\hline Sıcaklık ısının bir göstergesidir. & $\begin{array}{l}\text { Tiberghien, (2000); Başer ve } \\
\text { Çataloğlu, (2005) }\end{array}$ \\
\hline $\begin{array}{l}\text { Isı maddenin toplam sıcaklığıdır. } \\
\text { Isı, bir maddeye dokunduğundaki sıcaklık veya soğukluktur. } \\
\text { Isı, bir sıcaklıktır. } \\
\text { Sıcaklık maddenin sahip olduğu ısı değeridir. } \\
\text { Sıcaklık ortamdaki ısıya denir. } \\
\text { Bir maddenin belli derecedeki ısısıdır. } \\
\text { Sıcaklık, ölçülebilen ısı değeridir. } \\
\text { Sıcaklık, iki madde arasındaki ısı alış verişidir. } \\
\text { Sıcaklık, sıcak maddenin soğuk maddeye ısı vermesiyle oluşur. } \\
\text { Sıcaklık, maddenin içindeki ısı değeridir. } \\
\text { Sıcaklık, dışarıdan verilen bir ısıdır. } \\
\text { Sıcaklık, alınan veya verilen ısı miktarıdır. } \\
\text { Sıcaklık, ortama göre değişen ısı kapasitesidir. } \\
\text { Sıcaklık, ssının sahip olduğu değerdir. } \\
\text { Sıcaklık, hissedilen ısıdır. } \\
\text { Sıcaklık, ssının artıp azalmasıdır. } \\
\text { Sıcaklık, bir cismin sahip olduğu ısı ve nemin tamamıdır }\end{array}$ & Uzoğlu ve Gürbüz, (2013) \\
\hline
\end{tabular}

Damlı (2011)'nın çalışmasında, kavramsal değişim yaklaşımına dayalı web tabanlı etkileșimli öğretimin ön test- son test sonuçları arasındaki farkın çoğunlukla anlamlı olduğu tespit edilmiştir. Turgut ve Gürbüz (2011) çalışmasında; yapılandırmacı 5E modeline göre yapılan öğretimin geleneksel yöntemlere göre ısı ve sıcaklık kavramlarında, kavramsal değişimi ve kalıcılığı başarılı ve etkili olarak gerçekleştirdiğini ortaya çıkarmıştır. Yavuz ve Büyükekşi'nin (2011) çalışmasında; öğrencilerin sahip oldukları kavram yanılgılarını bilimsel fikirlere dönüştürmede kavram karikatürlerinin yardımı olduğu sonucuna ulaşılmıştır. Öner-Sünkür, 
İlhan ve Sünkür (2013) çalışmalarında; Tahmin- Gözlem- Açıkla (TGA) yönteminin doğrulama laboratuar yaklaşımına göre daha etkili olduğunu tespit etmişlerdir.

Öte yandan Harrison, Grayson ve Treagust (1999) araştırmalarında sorgulama temelli ısı ve sıcaklık kavramı öğretimi gerçekleștirmișler, ancak öğretim sürecinde kavramın tanımını yapmamışlar, ısı ve sıcaklık kavramlarının benzerlikleri ve farklılıklarının tartışılması istenerek öğretimi gerçekleştirmişlerdir. Çalışmanın sonucunda, ısı ve sıcaklık kavramlarının farklı oldukları ve daha bilimsel kabul edilebilir bir şekilde öğrendikleri tespit edilmiştir. Öğrenciler süreç sonunda daha etkili problem çözebilir ve bilişsel olarak üzerinde düşünebilir davranışlar göstermişlerdir. Başer (2006), tarafından yapılan çalışmada ise bilişsel çatışmanın ısı ve sıcaklık kavramlarının öğretiminde kavramsal değişime etkisinin olup olmadığı araştırılmıştır. Çalışmada sıcaklığın bilimsel tanımı yapılmadan, öğrencilerin sıcaklık kavramına ilişkin görüşleri, ıSı ve sıcaklığın özellikleri, ısı ve sıcaklığın hissedilmesi, ısı ve sıcaklığın artması ya da azalması bağlamında ortaya çıkarılarak, bilişsel çatışma ile öğretim gerçekleştirilmiştir. Sınıf öğretmeni adayları ile gerçekleştirilen araştırmada, Kavram Değerlendirme Testi kullanılmış ve çalışmanın sonucunda, bilişsel çatışma uygulanan deney grubunda kavramsal değişime olumlu etkiler gözlenmiştir. Benzer bir şekilde Başer ve Geban (2007) tarafından yapılan çalışmada, ıSı ve sıcaklık kavramlarını anlamada, kavramsal değişimin etkisi incelenmiştir. Ortaokul 7. sınıf öğrencileri ile gerçekleștirilen araştırmada, kavramsal değişim metinlerinin öğrencilerin kavramsal anlamalarının yanı sıra tutumları üzerine etkisi de tespit edilmiştir. Deney grubunda dersler, kontrol grubundan farklı olarak kavramsal değişim metinleri ile işlenmiştir. Araștırmanın sonucunda, kavramsal değișim metinlerinin, öğrencilerin mantıksal düşünmeleri üzerine de olumlu etkileri olduğu tespit edilmiştir. Çalışmalarında Jones ve diğerleri (2014), dokunsal simülasyonları kullanarak sıcaklık ve basınç konularının öğretimini gerçekleştirmişler ve çalışma grubunda yer alan 15 üniversite öğrencisi, dokunsal simülasyonlar kullanılarak gerçekleștirilen dersler sonrasında hazırlanan soruları cevaplamışlardır. Bu araştırmada da sıcaklığın tanımı yapılmadan, sıcaklık artışı ve sıcak-soğuk suyun molekülleri durumlarından yola çıkarak, sorulan sorulara verilen yanıtlara göre öğretim süreci tamamlanmıştır.

Genellikle sıcaklık kavramına ilişkin açıklamalar ısı kavramı ile benzerliği ve farklılı̆̆ı üzerine kurgulanmış ya da modeller kullanılmıștır. Sıcaklığın nasıl ölçülebildiğinden yola çıkarak sıcaklık kavramının tanımlanabileceği; bunun için de sıcaklı̆̆ın, cisimlerin boyutlarını nasıl etkilediği üzerinde durulması önemlidir. Sıcaklık, maddeye ait moleküllerin kinetik enerjisine bağlı olması; bu kavramı ısı ile karmaşık bir ilişki içerisine sokmaktadır. Bu yüzden sıcaklığı açıklamak için iyi bir giriş olmayacaktır. Sıcaklık ve ısı moleküler düzeye inilmeden de tanımlanabilir. Çünkü sıcaklık maddenin fiziksel durumuna bağlıdır. Radtka (2013) araştırmasında 1950-2000 yılları arasında Fransa, Polonya ve İngiltere'de okutulan fen ders kitaplarında sıcaklık konusunun nasıl yer aldığını ve ne şekilde öğretiminin gerçekleştirildiğini incelemiş, 50 yıllık süreci karşılaştırmalı olarak ele almıştır. 1950'ye kadar İngiltere, Fransa'da ve Polonya müfredatında sıcaklık kavramı, sıcaklığın ölçümü üzerinden tanımlanırken, 2000'li yıllara gelindiğinde İngiltere ve Polonya ders kitaplarında Fransa'nın aksine ısı ve sıcaklık kavramları tanecik teorisi ile ilişkilendirilmiştir. İngiliz ders kitaplarında isı iletkenliği mikroskopik seviyede açıllanmıştır. Bu durum kuramsal çerçevede doğru olmasına rağmen, sıcaklık konusuna giriş için negatif etkileri olmuştur. Oysa Fransa'da okul kitaplarında eski tip veya dijital termometreler yer almaktadır. Yani sıcaklığı, ölçüm aleti termometre üzerinden değerlendirmektedir. Günümüz Fransa ders kitaplarında sıcaklık kavramı, maddenin halleri ve maddenin fiziksel özellikleri ünitesinde işlenmektedir.

Özetle, alan yazında yer alan çalışmalarda, sıcaklığın öğretiminde ciddi arayışların olduğunu ve henüz öğrencilerin sıcaklık ile ilgili kavram oluşturmada istenilen seviyeye ulaşılamadığı söylenebilir. Isı ve sıcaklık kavramları aslında birbirinden farklı olmasına rağmen, eğitim araştırmalarının birçoğunda birlikte ele alınmıştır. İncelenen çalışmaların bir kısmında, "Isı ve Sıcaklık" ile ilgili kavram yanılgıları çeşitli yaş ve öğrenim seviyelerinde tespit edilmiştir (örn., Gürdal, 2008; Bayram, 2010; Thomaz, Malaquias, Valentean ve Antunes, 1995; Uzoğlu ve Gürbüz, 2013). Bir kısmında ise çeşitli yöntem ve teknikler kullanılarak geleneksel yaklaşıma göre kavram yanılgıları açısından aralarındaki farklar olduğu belirlenmiştir (örn., Jones ve 
diğerleri, 2014; Öner-Sünkür, İlhan ve Sünkür, 2013). Öte yandan incelenen bu çalışmalarda ısı ve sıcaklık kavramlarını tanımlamaktan kaçınılmış, özellikleri doğrultusunda bu kavramlar ele alınmıştır. Mevcut araştırmada ısı kavramından bağımsız bir şekilde sıcaklık kavramının öğrencilere aktarılması sorgulama temelli bilim eğitimi ışığında gerçekleştirilecektir. Bu nedenle kısaca alan yazımdan yararlanarak araştırmanın öğretim felsefesine açıklık getirmek amacıyla sorgulama temelli bilim eğitimi yaklaşımına kısaca değinilecektir.

\section{Fen Bilimleri Eğitiminde Sorgulama Temelli Yaklaşım}

Günümüzde fen bilimleri alanında sınıf içi bilimsel etkinliklere basılı veya elektronik olarak ulaşmak sanal ortam sayesinde oldukça kolaylaştı. Pek çok program bu hizmeti öğretmenlere sunmaktadır. Ancak öğretmenlerin ve öğrencilerin bu deneyleri basit malzemeler eşliğinde, açıklamaları takip ederek gerçekleștirmesi veya öğretmenin rehberliğinde sırası ile uygulaması öğrencilerin bilimsel düşünme becerilerinin geliştirildiği anlamına gelmez. Ögrrencinin etkinliklere katılıyor ve etkinlikleri yapıyor olması da aktif bir bilim eğitimi gerçekleștiriliyor demek değildir. Burada asıl önemli olan öğretmenin etkinliği hazırlama ve gerçekleștirme sırasında izleyeceği stratejilerdir (Bell, Smetana ve Binns, 2005; Oguz-Unver ve Arabacioglu, 2014). Sınıf içinde kullanılan etkinlikler sadece öğrencilerin sorgulama ve deneyimlerine hizmet eden araçlardır (Bell, Blair, Lederman ve Crawford, 2003). Önemli olan etkinlik sırasında öğrenciler arasındaki diyalog ve tartışmalar ile sorgulamanın desteklenmesidir (Cuevas, Lee, Hart ve Deaktor, 2005; Bybee, 2006; Lederman, 2006; Harlen, 2014).

Sorgulama temelli bilim eğitimi, zihinsel süreç becerilerini geliștirmeye yönelik olması nedeniyle bireyin öğretim sürecine aktif olarak katılmasını gerektirmektedir. Bilim eğitiminin sorgulama ile gerçekleştirilmesi buna imkân sağlamaktadır. Sorgulama temelli bilim eğitiminin genel hedefi "Hiç kimse her şeyi öğrenemez; fakat herkes öğrenmeyi öğrenebilir" düşüncesini benimseyerek bireye öğrenme becerisi ve öğrenmeye karşı olumlu tutum geliştirmesini sağlamaktır (Harlen, 2014). Bunun yanında özel hedef ise bireylerin eleştirel düşünme becerisini geliştirmektir (Magnussen, Ishida ve Itano, 2000). Sorgulama temelli bilim eğitimi süreci, gözlemlere dayanan bir sorunun bireylere sorulması ile başlar, kanıtlara dayanan tartışma ve uygulamalarla sona erer (Cuevas, Lee, Hart ve Deaktor, 2005). Başlangıçta bireylere yöneltilen sorunun eleştirel düşünme becerisini geliştirici özelliği olmalıdır. Bu sorular eleştirel düşünme soruları olarak adlandırılır (Spencer, Farrell ve Moog, 1999).

$\mathrm{Bu}$ nedenle, mevcut araştırmanın amacı, ortaokul öğrencileri ile öğretmen adaylarının, sıcaklığın ölçümünden yola çlkarak; sıcaklık kavramı ve ölçümüne ilişkin bilgi ve becerilerinin değerlendirilmesi ve sorgulama temelli bilim eğitimi çerçevesinde gerçekleștirilen etkinlik sonrası edindikleri bilgi ve becerileri bir ürüne aktarabilme düzeyleri incelenmesi amaçlanmıștır. Katılımcılardan süreç sonrası termometre tasarlamaları istenmiștir. Sonuç olarak, araştırmanın problem cümlesi "Ortaokul öğrencileri ile fen bilgisi öğretmen adaylarının sıcaklığın ölçümünden yola çıkarak sıcaklık kavramına ait bilgilerinin düzeyleri nedir?” Buna bağlı araştırmanın alt problemleri;

1-) Sıcaklığın ölçümünden yola çıkarak Fen Bilgisi Öğretmen adaylarının sıcaklık kavramına ait ön bilgileri nelerdir?

2-) Sıcaklığın ölçümünden yola çıkarak ortaokul öğrencilerinin sıcaklık kavramına ait ön bilgileri nelerdir?

3-) Sıcaklığın ölçümünden yola çıkarak Fen Bilgisi Öğretmen adayları ve ortaokul öğrencilerinin sıcaklık kavramına ait ön bilgileri arasındaki farklar ve benzerlikler nelerdir?

4-) Sıcaklık kavramının ısı kavramından bağımsız maddenin fiziksel durumuna bağlı bir nicelik olarak Sorgulama Temelli Bilim Eğitimi (STBE) çerçevesinde aktarılmasının ardından Fen Bilgisi Öğretmen adayları ve ortaokul öğrencilerinin tasarladıkları termometrelerin nitelikleri nelerdir? 


\section{YÖNTEM}

\section{Araștırmanın Modeli ve Katılımcıları}

Araştırma nitel araştırmada eylem araştırması türünde desenlenmiştir. Eylem araștırmaları; uzman araștırmacıların yürütücülüğünde, uygulayıcıların ve probleme taraf olanların da katılmasıyla, var olan uygulamanın eleştirel bir değerlendirmesini yaparak, durumu iyileştirmek için alınması gereken önlemleri belirlemeyi amaçlamaktadır (Karasar, 2003). Aşağıdaki Tablo 2'de araştırma sürecinin daha net anlaşılması amacıyla uygulama ve değerlendirme süreçleri özetlenmiştir.

Tablo 2. Araştırma süreci

\begin{tabular}{|c|c|c|c|c|c|}
\hline & 1. Aşama & 2. Aşama & 3. Aşama & 4. Aşama & 5. Aşama \\
\hline İşlem & $\begin{array}{l}\text { Uygulama: } \\
\text { Yönlendirme } \\
\text { olmaksızın } \\
\text { hava } \\
\text { sıcaklığının } \\
\text { ölçümü }\end{array}$ & \begin{tabular}{l}
\multicolumn{1}{c}{$\begin{array}{c}\text { Değerlendir } \\
\text { me: }\end{array}$} \\
Sicaklığa iliş̧in \\
mevcut \\
bilgilerin ve \\
ölçme \\
becerilerinin \\
sinıf ortamında \\
sorgulanması/ \\
değerlendiril \\
mesi
\end{tabular} & $\begin{array}{l}\text { Uygulama: } \\
\text { STBE } \\
\text { etkinlikleri }\end{array}$ & $\begin{array}{c}\text { Proje } \\
\text { hazırlama }\end{array}$ & $\begin{array}{l}\text { Değerlendirme } \\
\text { Termometre } \\
\text { tasarımlarının } \\
\text { değerlendirilmes } \\
\text { i }\end{array}$ \\
\hline $\begin{array}{l}\text { Kullanı } \\
\text { lan } \\
\text { araçlar }\end{array}$ & Termometreler & $\begin{array}{c}\text { Etkinlik çalışma } \\
\text { yaprağı (Ek.1) }\end{array}$ & $\begin{array}{c}\text { 1.Buz } \\
\text { etkinliği } \\
\text { 2.John } \\
\text { Locke } \\
\text { etkinliği } \\
\text { 3.Farklı } \\
\text { türde } \\
\text { termometre } \\
\text { etkinliği }\end{array}$ & $\begin{array}{c}\text { Öğrenci } \\
\text { projeleri } \\
\text { sonucu } \\
\text { tasarlanan } \\
\text { termometreler }\end{array}$ & $\begin{array}{c}\text { Termometre } \\
\text { değerlendirme } \\
\text { formu (Ek.2) }\end{array}$ \\
\hline
\end{tabular}

Araştırmanın katılımcıları; Batı Anadolu'da yer alan ilçe devlet ortaokulunun beşinci $(\mathrm{N}=19$ kız; $\mathrm{N}=15$ erkek), altıncı $(\mathrm{N}=12 \mathrm{kız} ; \mathrm{N}=13$ erkek), yedinci $(\mathrm{N}=14 \mathrm{kız} ; \mathrm{N}=11$ erkek) ve sekizinci (N=11 kız; N=14 erkek) sınıfında öğrenim görmekte olan toplam 109 ortaokul öğrencisi ve bu okulun bağlı olduğu il merkezinde yer alan bir devlet üniversitesi Eğitim Fakültesi Fen Bilgisi Öğretmenliği ABD. 3. sınıfta öğrenim görmekte olan 77 öğretmen adayı (N=37 erkek; N=40 kadın) olușturmaktadır. Farklı eğitim düzeylerine sahip olan öğrencilerin sıcaklık kavramına ilişkin bilgilerinin ve ölçme becerilerinin sorgulanması ve karşılaştırılması imkân tanıyabilecek çalışma grubunun belirlenmesinde amaçlı örnekleme yöntemlerinden kolay ulaşılabilir durum örneklemesiyle katılımcılar seçilmiştir. Böylelikle karşılaştırmalı araştırma yapabilmek amacıyla çalışmanın amacı bağlamında bilgi açısından zengin bir örnekleme seçilmeye çalışılmıştır. Ayrıca zaman, para ve işgücü açısından var olan sinırlılıklar nedeniyle örneklemin kolay ulaşılabilir ve uygulama yapılabilir birimlerden seçilmiştir.

\section{Araştırmanın uygulamaları ve veri toplama}

Çalışmanın birinci aşamasında; öğrencilere "Şu anda havanın sıcaklığı nedir? Nasıl ölçeriz?" sorusu yöneltilerek termometreler dağıtılmış ve hiçbir yönlendirme ve ek bilgi verilmeksizin hava sıcaklığını ölçmeleri ve sonuçlar ile birlikte araştırmacılarca geliştirilmiş çalışma yapraklarına (Ek.1) bu süreci özetlemeleri istenmiştir. Çalışma yaprağında hava sıcaklığının ölçüm sürecini ve elde edilen ölçüm sonucunu değerlendirmek ve ölçüm sonucuna ilişkin öğrencilerin düşüncelerini belirlemek amacıyla sorulara yer verilmiştir. Öğrencilerin termometre kullanma becerilerini ve ölçme sonuçlarına ilişkin düşüncelerini değerlendirmek 
için hazırlanan çalışma yaprağı uzman görüşleri ve pilot çalışmalar neticesinde şekillendirilmiştir. Rehberli sorgulama gereği öğretmen, hava sıcaklığı ölçümü problemine ilişkin öğrencilerin kendi çözüm yöntemlerini geliștirmelerini beklemiştir. 2-3 kişilik gruplara ayrılan öğrenciler dağıtılan termometreler ile istedikleri yer (gölge, güneș, dış mekan, iç mekan vb.) ve yöntem ile (termometre tutuş, zemin, çoklu ölçüm vb.) havanın sıcaklığını ölçmüşlerdir. Sonrasında sınıf içi tartışmalarda araştırmacı tarafından, öğrencilerin veri toplama ve ölçüm tekniklerinin sorgulandığı açık uçlu sorular yöneltilmiştir. $\mathrm{Bu}$ sorular önceden yapılandırılmamıș, yaklaștırılmak istenen kavrama ilişkin öğrencilerin düşünceleri doğrultusunda rehberli sorgulama ışığında o anda oluşturulmuştur.

İkinci aşamada gruplar hava sıcaklığına ilişkin bir ölçüm sonucuna varmaya çalışarak; ölçme ve sıcaklığa ilişkin bilgi, beceri ve davranışlarını ortaya çıkarmayı hedefleyen sorular sorulmuştur. Öğrencilerin kendi aralarındaki tartışmaları, sıcaklık ölçümü yaparken izledikleri yöntemler ve mevcut bilgiler, araştırmacılar tarafından not edilmiştir. Etkinliğin sonunda gruplar sonuçlarını sınıf ile paylaşarak sınıfta tartışma ortamı oluşturulmuştur.

Çalışmanın üçüncü aşamasında okul kitaplarında (buz etkinliği, farklı türde termometreler) ve alan yazında (John Locke etkinliği) yer alan ancak araştırmacılar tarafından sınıf seviyesine göre yeniden gözden geçirilmiş etkinliklere yer verilmiştir. Son olarak da araştırmacılar tarafından geliştirilen 'termometre tasarımı etkinliği' uygulanmıştır. Bu etkinliklerin seçilme nedenleri öğrencilerin sıcaklık kavramının doğasına yaklaştırmak ve sıcaklığa bağlı değişkenlere dikkat çekmektir. Aşağıda araştırma sürecinde uygulanan etkinlikler açıklanmıștır.

\section{Buz etkinliği}

Buz etkinliğinde aynı sıcaklıkta bulunan farklı miktarlarda (Örn. bir sürahi su -1,5 L ve bir su bardağı suyun - 200mL) suların yer aldığı kapların içerisine aynı kütlede buz küpleri bırakılır (Şekil 1). Kapların ağızları streç film ile kapatılır ve kapalı ortam oluşturulur. Öğrencilere hangi buzun önce eriyeceği sorulur; tahminlerini not etmeleri istenir. Buzların erime süreleri tespit edildikten sonra sorular ile mevcut gözlemde öğrencilerin bilimsel bir açılama getirebilmeleri teşvik edilir.

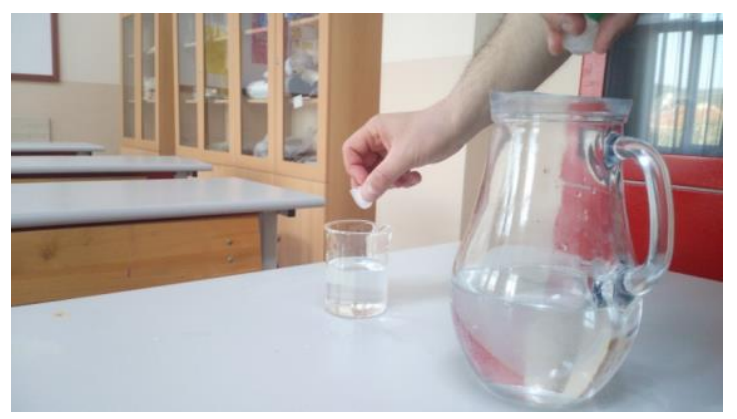

Şekil 1. Buz etkinliğinden görüntüler

\section{John Locke etkinliği}

Etkinlik John Locke tarafından 1690 yılında gerçekleştirilen basit deneyi konu almaktadır. Üç özdeş kaba aynı miktarda, sıcak $\left(\sim 38{ }^{\circ} \mathrm{C}\right)$, llık $\left(\sim 22{ }^{\circ} \mathrm{C}\right)$ ve soğuk su $\left(\sim 0{ }^{\circ} \mathrm{C}\right)$ sıralaması ile sular konulur. Öğrencilerden ilk önce bir elini sıcak, diğerini ise soğuk su içerisinde bir süre tutması istenir (Şekil 2). Eller bu sular içerisinde bir süre bekledikten sonra hiç zaman kaybetmeksizin çıkarılarak ortada bulunan ılık suya sokmaları istenir. Bu durumda ılık suyun soğuk mu? yoksa sıcak mı? olduğu sorularak bir karar verilmesi beklenir. Burada sıcaklığın duyularımızla tanımlanmasının yanıltıcılığı nedeniyle etkinliği gerçekleştiren öğrenci bir karar verememektedir. Etkinlikte katılımcılara aynı suyu bir elimiz sıcak hissederken diğer elimiz soğuk hissetmesinin nedeni sorularak tartışma ortamı oluşturulmuştur. 


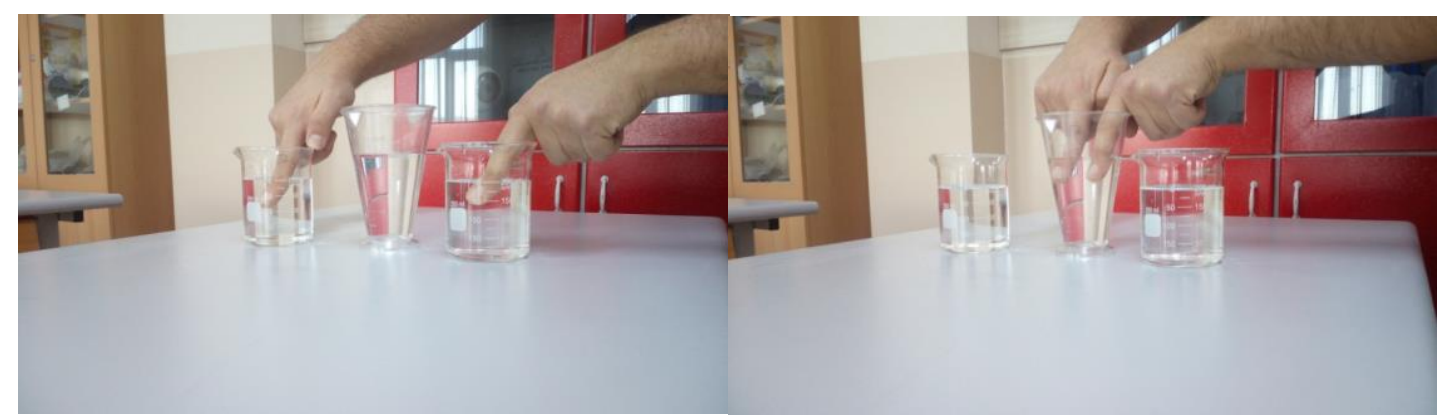

Şekil 2. John Locke etkinliğinden görüntüler

\section{Farklı türde Termometre etkinliği}

Farklı türlerde termometre etkinliği Oğuz-Ünver (2015)'den uyarlanmıștır. Etkinlikte sicaklık ölçme aracı termometrenin gerçekte ne olduğunu ve hangi prensibe göre çalıştığı sorgulanmıştır. Bunun için aşağıdaki Şekil 3'deki örnekleri sunulan bazı termometre türleri öğrencilere dağıtılarak öğrencilerin termometrelere ilişkin gözlem yapmaları beklenmektedir.
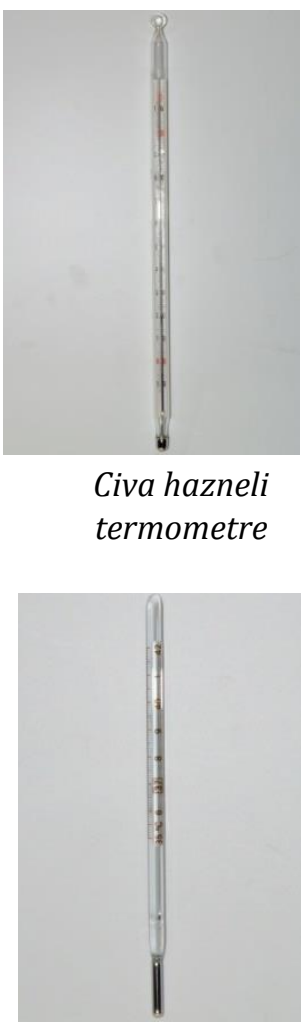

Klinik termometre

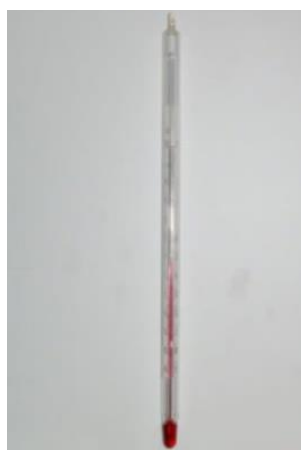

Alkol hazneli termometreler

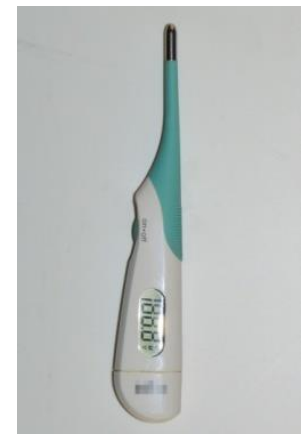

Dijital termometreler

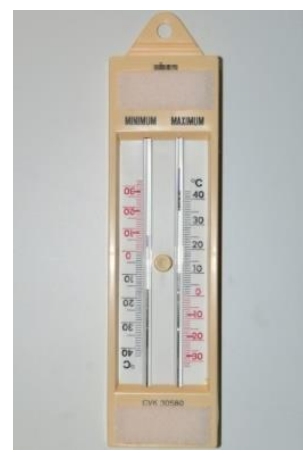

Maksimum ve minimum termometre

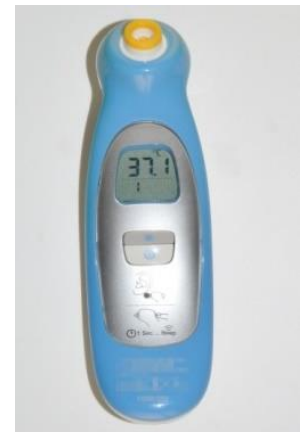

Şekil 3. Farklı türde termometreler etkinliğinde kullanılabilecek termometrelere ilişkin örnekler

Etkinliklerde amaç, öğrencilere termometrenin çalışma prensibinden yola çıkılarak sıcaklık kavramını algılamaları ve öğrencilerin maddenin makro niceliklerinin değişimini göz önünde bulunarak kendi termometrelerini geliştirmelerinde fikir verebilmektedir.

Çalışmanın dördüncü aşamasında öğrencilerden sıcaklığın parametrelerinden yola çıkarak bir termometre tasarımı yapmaları istenir.

\section{Termometre tasarımı etkinliği}

Önceki üç etkinlikte sıcaklık kavramına ilişkin bilgi ve ölçümüne ilişkin temel becerilerin kazandırılmaya çalışıldığı katılımcı grubuna sıcaklık ölçümünün farklı parametreler (sıvıların 
hacimlerinin değişmesi, katıların uzunluğunun değişmesi, sabit hacimdeki bir gazın basıncının değişmesi, sabit basınçtaki bir gazın hacminin değişmesi, bir iletkenin elektrik direncinin değişmesi, cisimlerin renk değiştirmesi) üzerinden yapabileceğini fark etmeleri amaçlanmıştır. Gönüllü katılımcılardan basit ve ucuz malzemeler kullanarak verilen parametrelerden birini kullanarak kendi termometrelerini tasarlamaları istemiştir. Öğrencileri yönlendirmemek adına malzemeleri kendileri temin etmişlerdir. Bu sırada öğrencilerin tasarım fikirlerine müdahale etmeden yardımcı olunmuştur. Bu etkinlik bir bakıma öğretim sürecinin öğrencilerdeki etkililiğinin bir değerlendirmesidir.

Araştırmada kullanılan diğer bir veri toplama aracı ise termometre tasarımlarının değerlendirilmesine imkân tanıyan Oğuz Ünver (2015) tarafından geliștirilen termometre değerlendirme formudur (Ek.2). Değerlendirme formu (1) Termometre gerçeğe ne kadar yakın? (2) Termometre hangi ilkeye göre tasarlanmış? (3) Termometre hangi maddelerin sıcaklığını ölçüyor? (4) Termometrenin tasarımı ve işlevselliği nasıl? sorularına karşılık gelen dört ana temada oluşturulan ve proje ürünlerinin değerlendirmesine imkân tanıyan bir ürün değerlendirme ölçme aracıdır. Böylece öğrencilerin sıcaklığın ölçümünden yola çıkarak STBE anlayışıyla gerçekleștirdikleri etkinlikler sonrası elde ettikleri bilgi ve becerilerin proje ürünleri olan termometrelerin tasarımına aktarılabilme düzeyleri değerlendirilme imkânı bulmaktadır.

\section{Verilerin Analizi}

Katılımcıların çalışma yapraklarından elde edilen veriler içerik analizi ile incelenmiştir. İçerik analizinde temel amaç, toplanan verileri açıklayabilecek kavramlara ve ilişkilere ulaşmaktır. Yıldırım ve Şimşek, (2011: 227)' e göre içerik analizi süreci şu şekilde gerçekleştirilir, veriler derin analize tabi tutulur. $\mathrm{Bu}$ amaçla toplanan verilerin önce kavramsallaştırılması daha sonra da ortaya çıkan kavramlara göre mantıklı bir biçimde organize edilerek temaların saptanması gerekmektedir. Bu aşamada araştırmacı, elde ettiği bilgileri inceleyerek, anlamlı bölümlere ayırır ve her bölümün kavramsal olarak ne anlam ifade ettiğini anlamaya çalışır. Oluşturulan anlamlı bölümlere tanımlayıcı isimler yani kodlar verilir. Verilen bu kodlar; araştırmacının kendisinden, okuduğu alan yazından ya da verinin içinden çıkarılabilir. $\mathrm{Bu}$ çalışmada kullanılan kodlama yöntemi, toplanan verilerden elde edilen kavramlara göre yapılan kodlamadır. Veriler, araştırmacı tarafından birçok kez okunarak araştırmanın problemleri doğrultusunda kişilerin yazılı ifadelerine bağlı kalınarak kodlanmıştır. Kodlar öncelikle serbest kodlar șeklinde hazırlanmış, daha sonra bu serbest kodlar özelliklerine bağlı olarak belli temalar altında gruplandırılmıștır.

Araştırmanın veri toplama araçlarından bir diğeri öğrenciler tarafından tasarlanan termometrelerdir. Gönüllü öğrenciler tarafından tasarlanan termometreler; Oğuz-Ünver (2015) tarafından geliștirilen termometre değerlendirme formu ile üç uzman tarafından ayrı ayrı değerlendirilmiş ve puanlanmıștır.

\section{BULGULAR}

\section{Sıcaklığın Ölçümünden Yola Çıkarak Fen Bilgisi Öğretmen Adaylarının Sıcaklık Kavramı Düşünceleri}

Öğretmen adaylarının havanın sıcaklığını ölçmeleri sonucu, çalışma yapraklarından ve sınıf içindeki tartışma ortamından elde edilen veriler Tablo 3'de termometrenin kullanım şekli, hava sıcaklığın ölçüldüğü ortam ve termometrenin yapısı başlıkları altında temalandırılmıștır. 
Tablo 3. Öğretmen adaylarının hava sıcaklı̆̆ı ölçümlerine ilişkin bulguları

\begin{tabular}{|c|c|}
\hline Tema & Kod \\
\hline \multirow{3}{*}{$\begin{array}{c}\text { Termometrenin } \\
\text { Kullanım Şekli }\end{array}$} & Termometreyi dik tutmak \\
\hline & Termometreyi yalıtkan bir madde ile asarak sabitlemek \\
\hline & Termometreyi yatay tutmak \\
\hline \multirow{3}{*}{$\begin{array}{l}\text { Hava Sıcaklığının } \\
\text { Ölçüldüğü Ortam }\end{array}$} & Rüzgarda \\
\hline & Önce gölge sonra güneşli ortamda ölçüm ve ortalaması \\
\hline & Termometrenin yerden yüksekliği \\
\hline \multirow{2}{*}{$\begin{array}{c}\text { Termometrenin } \\
\text { Yapısı }\end{array}$} & Termometrede kullanılan sıvının türü \\
\hline & Termometrede kullanılan sıvının rengi \\
\hline
\end{tabular}

Öğretmen adaylarına dağıtılan çalışma kâğıdında, dikkati toplama sorusu "havanın sıcaklığını nasıl ölçtünüz?" dür. Öğrenciler sıcaklığı yerçekimi ile ilişkilendirerek termometrenin dik tutulması gerektiğini vurgulamışlardır.

ÖA3 "Termometreyi dik tutarak ölçtüm. Çünkü yerçekimini dâhil etmeliyim", ÖA43

"Termometreyi dik tutarak ölçtüm. Çünkü dik konumda olduğu zaman yer çekimine karşı maksimum etki edeceğinden doğru sonucu alırız."

şeklinde cevaplar alındı. Öğrencilere, termometreyi neden yatay konumda tutmadıkları sorulduğunda, öğrencilerin verdikleri cevaplardan elde edilen bulgular,

ÖA7“Çünkü yatay konumdayken termometreye gelen güneş ışınları dik olur. Bu durumda doğru sonucu alamayız." ÖA21“termometre yatay konumdayken, güneşı ışığı ile teması daha fazla olacağı için sıcaklık ölçümünü etkiler" ÖA1"termometre dengeli durmalıdır. Yatay konumda doğru ölçüm yapmaz." ÖA13 "termometreyi ip gibi yalıtkan bir madde ile asılınca doğru sonuç alırız"

bazı öğrenciler ise dik tutmalarının sebebini;

ÖA22 "daha rahat okuyabiliriz." ÖA30 "ben hep böyle gördüm." ÖA63 "havanın sıcaklığını ölçmek için herhangi bir yere dik olarak asılmalıdır."

şeklinde ifade etmişlerdir. Ayrıca öğrenciler termometrede kullanılan sıvının kullanımı etkilediğini vurgulamışlardır. Örneğin;

ÖA31 "yatay konumda tutsaydım içerisindeki cıva hareket ederdi." ÖA62 "yatay konumda clva hareketlidir." ÖA71 "cıva akışkan olduğu için dik tutulmalıdır." Ö52 "cıva sıvıdır, dökülmesin."

Tüm bu tartışmaların ardından öğrencilere "Ateşimiz çıktığında koltuk atından vücudumuzun sıcaklığını nasıl ölçeriz?" sorusu yöneltildiğinde öğrencilerden termometrenin yatay olarak kullanılması gerektiğini belirtenler:

ÖA9 “cıva yatay konumda daha fazla genleșir, o yüzden dik konulmamalıdır.” ÖA13 "Termometreyi yatay tutarak ölçtüm. Cünkü hava sıcaklığını maksimum alması için dışarıda yatay konumlandırılmalıdır", ÖA15 "Termometreyi yatay konumdayken hava ile teması daha fazla olur. Buda ölçümü güvenilir duruma getirir." , ÖA64 "termometre, yatay konumda hava ile daha çok temas var".

türünde ilginç cevaplar alınmıştır. Öğrencilere "Termometrelerde camdan oluşan ince bir kılcal boru ve bir hazne yer almaktadır. Bu cam bölümün tamamı sıcaklığa duyarlı mıdır?" sorusuna;

ÖA38 "termometreyi tutarken cam boru kısmına dokunmadım. Çünkü elimin ısısı termometreye geçebilirdi." ÖA53 "termometreyi cam çubuğundan tutmadım çünkü elimin IsIsı geçerdi."

şeklinde cevaplamışlardır.

Öğretmen adaylarına "havanın sıcaklığının ölçmek için nasıl bir planlama yaptınız? sınıfta anlatabilir misiniz?" sorusuna gelen yanıtlar rüzgarlı, önce gölge sonra güneşli ortamda ölçüm ve ortalaması ile termometrenin yerden yükseklik kodlarında yoğunlaşmıștır. 
ÖA76 "Rüzgârlı havada rüzgârın farklı yönlerde esmesi sıcaklığı etkileyeceği için rüzgarlı havalarda ölçüm yapılamaz", ÖA48 "Rüzgar termometredeki sıcaklığı değiştirir", ÖA47 "Rüzgar termometredeki sıcaklığı düşürür" ifadesiyle rüzgarı vurgularken, ÖA3 "güneşli ortamda ölçtük çünkü gölge çok soğuktu"

ifadeleriyle güneş ve gölge ortamları tartışmaya açllmıştır. Tartışmadaki diğer bir görüş

ise

ÖA21"güneș ışınları etki ettiği için ölçümlerin gölgede yaptık", ÖA51 "her konumda ayrı ayrı ölçümler alınarak aritmetik ortalaması bulunur, bu da havanın gerçek sıcaklığıdır", ÖA5 "sıcaklık ölçümlerini, güneşışınların etki ettiği yer ve gölgede yaparak, ortalamasını aldık", ÖA1 "güneş ışınları dik gelince ısı birikiminden dolayı şeffaf bir ölçüm gerçekleşmez"

ifadeleri ile sıcaklık ölçümlerini gölge-güneş ve rüzgarlı ortamlarda ölçülmesi gerektiği tartışılmıştır. Öte yandan tartışma ortamında sorgulanan bir diğer nokta termometrenin konumudur.

ÖA8 "termometre ISl yalıtkanı toprağa temas ederek doğru sonuca ulaştık", ÖA22 "yukarı çıkıldıkça hava sıcaklığı düşeceğinden yerde ölçüm yaptık" ifadeleri ile yere yakın ölçümü tartışıldı. ÖA61 "amaç havanın sıcaklığını ölçmek olduğu için termometre toprağın sıcaklığından etkilenmemesi amacı ile, yerden yüksekte ısı yalıtkanı olan ağaç dalına asarak ya da tahta bankların üzerine koyarak ölçümü yaptık”

ifadelerine rastlandl.

Öğretmen adaylarının termometrede olması gereken özellikler ile ilgili sorulara verdikleri cevaplarda, içerisinde kullanılan sıvı ve sıvının rengi üzerinde yoğunlaştığı görülmüştür. Termometre içerisinde yer alan sıvının türü sorulduğunda gelen cevapların büyük bir kısmı termometrelerde cıva kullanıldığı, ancak bazı öğrencilerin cıva dışında alkolde kullanıldığı belirtilmiştir.

ÖA62 "termometre içerisinde bulunan sivi her zaman clva olmalıdır", ÖA81 "Termometrenin hassas olabilmesi için cıva kullanılmalıdır" ÖA53 "cıvalı termometreler, duyarlı ölçüm yapar", ÖA03 "cıva dışında kullanılacak farklı sıvılarda termometrenin boyunun uzamasına neden olacaktır", ÖA27 "cıvanın donma sıcaklı̆̆ı yüksek olduğu için termometrelerde kullanılmalıdır" Aynı öğretmen adayına donma sıcaklığı ile ne kastettiği sorulduğunda, "cıva oda sıcaklığında sıvı olmasından dolayı daha doğru ölçüm yapar"

şeklinde ifade edildi. Bu tartışmalarda termometredeki sıvının cıva olması gerekliliği üzerinde yoğunlaştığı görülmüştür. Buna karşın cıva yerine farklı sıvılarda kullanılabileceğini belirten düşünceler, öğretmen adaylarınca ifade edilmiştir.

ÖA22 “ Termometreye alkol konulmalı çünkü donma sıcaklığı düşük olduğu için ölçüm aralığı daha geniştir" ÖA12 "Termometrelerde cıva yerine başka bir sıvı kullanılmall, çünkü cıva metalle etkileşime geçer".

Dikkat çeken bir diğer ifade ise

ÖA51 "kırmızı renkli sıvlya sahip termometreler sıcağa duyarll, mavi renkli olanlar soğuya duyarlıdır"

Öğretmen adaylarının bu konuda verdikleri cevaplar incelendiğinde termometrede kullanılan sıvının cıva olması ya da bașka bir sıvı olması üzerine yoğunlaştığı ayrıca kullanılan sıvıların renklerine de bir anlam yükledikleri görülmüştür.

\section{Sıcaklığın Ölçümünden Yola Çıkarak Ortaokul Öğrencilerinin Sıcaklık Kavramına İlişkin Düşünceleri}

Ortaokul öğrencilerinin havanın sıcaklığını ölçmeleri sonucu, çalışma yapraklarından ve sınıf içindeki tartışma ortamından elde edilen veriler Tablo 4'de termometrenin kullanım şekli, hava sıcaklığın ölçüldügü ortam ve termometrenin yapısı başlıkları altında temalandırılmıştır.

Ortaokul öğrencilerine dağıtılan çalışma kâğıdında, dikkati toplama sorusu "havanın sıcaklı̆̆ını nasıl ölçtünüz?" ifadesidir. Öğrenciler sıcaklığı ölçerken termometrenin dik ya da yatay tutulmasının önemli olmadığını vurgulamışlardır. Örneğin, OÖ5 “Termometreyi dik tutarak ölçtüm, sonra yatay olarak ölçtüm”, Ortaokul öğrencisine neden iki farklı konumda ölçüm yaptığı sorulunca "ölçümün değişip değişmediğini görmek istedim" şeklinde cevaplamıştır. Benzer bir 
yanıtı $00 ̈ 42$ "Termometreyi çapraz tutarak ölçtüm. Çünkü dik konumda bulduğum değerle karşılaştırmak istedim." șeklinde yanıtlanmıştır.

Tablo 4. Ortaokul öğrencilerin hava sıcaklığı ölçümlerine iliş̧in bulguları

\begin{tabular}{cl}
\hline Tema & \multicolumn{1}{c}{ Kod } \\
\hline \multirow{2}{*}{$\begin{array}{c}\text { Termometrenin } \\
\text { Kullanım Şekli }\end{array}$} & Termometreyi dik tutmak \\
\cline { 2 - 2 } & Birden çok ölçüm yapmak \\
\cline { 2 - 2 } $\begin{array}{c}\text { Hava Sıcaklığının } \\
\text { Ölçüldüğ̈ü Ortam }\end{array}$ & Termometre yüksekliği \\
\cline { 2 - 2 } $\begin{array}{c}\text { Termometre gölge sonra güneşli ortamda ölçüm ve ortalaması } \\
\text { Yapısı }\end{array}$ & Termometrede kullanılan sıvının türü \\
\hline
\end{tabular}

Öğrencilere, termometreyi neden yatay konumda tutmadıkları sorulduğunda, öğrencilerin verdikleri cevaplardan aşağıda yer almaktadır,

0Ö7“Cünkü termometreyi dik yada yatay tutmak önemli olsaydl, termometreyi ona göre yaparlardı." 0Ö1“termometreyi düz kullanmalıyız, çünkü üzerinde yer alan rakamları daha kolay okuyabiliriz."0Ö10“termometreyi ters kullanamayız, çünkü içerisinde yer alan sivı akar."

Bazı öğrenciler ise dik tutmalarının sebebini; 0Ö12 "daha rahat okuyabiliriz." oÖ20 "öğretmenimden böyle gördüm." ş̧eklinde ifade etmişlerdir. Ortaokul öğrencilerine Ölçüm sonuçlarınıza güveniyor musunuz" sorusuna verdikleri cevaplarda; tekrarlı ölçümler yapıldığı, farklı termometrelerin kullanıldığı ve farklı noktalarda ölçüm yaparak sonuçlarına güvendiklerini ifade edildiği görülmüştür. Örneğin;

00̈31 "farklı termometreler kullanarak ölçümü tekrarladı̆̆ım için sonucuma güveniyorum." $00 ̈ 71$ "diğer gruptaki arkadaşlarımda benimle aynı sonucu buldu." $00 ̈ 11$ "Aynı termometre ile farklı arkadaşlarımla birden çok ölçüm yaptığım için sonuç doğrudur." 0Ö52 "Termometre ile birden çok ölçüm yaptım, sonrasında ölçümlerin ortalamasını aldığım için sonucuma güveniyorum."

Termometrenin dik tutularak kullanılması gerektiğini vurgulayanların yanı sıra yatay olarak kullanılması gerektiğini belirtenler görülmüştür. $00 ̈ 19$ "termometreyi beyaz zemine yatay koyarak etkilenmesini engelledim." Bir diğer öğrenci 0Ö15 "Termometreyi yatay olarak kâğıdın üzerine koydum" ifadesinde "neden kağıdı seçtin?" sorusuna verdiği cevapta aynı öğrenci "termometre metalin üzerine konulmaz, çünkü metal sıcaklığını hemen termometreye verir" ifadesi dikkat çekicidir.

Öğrencilere "Termometrelerde camdan oluşan ince bir kılcal boru ve bir hazne yer almaktadır. Bu cam bölümün tamamı sıcaklığa duyarlı mıdır?" sorusuna; 00̈32 "termometreyi tutarken cam boru kısmına dokunmadım. Çünkü elimin ısısı termometreye geçebilirdi." ifadesinin yanı sıra bir diğer öğrenci $00 ̈ 54$ "termometreyi sıvı haznesinden tutmadım çünkü elimin ısısı geçerdi." şeklinde cevaplamışlardır.

Ortaokul öğrencilerine "havanın sıcaklığının ölçmek için nasıl bir planlama yaptınız? sınıfta anlatabilir misiniz?" sorusuna gelen yanitlar önce gölge sonra güneşli ortamda ölçüm ve ortalaması ile termometrenin yerden yükseklik kodlarında yoğunlaşmıștır. OÖ23 "güneşli ortamda ölçtük çünkü herkes gölgede ölçtü.", OÖ22"termometre ile güneş ve gölgede hava sıcaklıklarını ölçerek karşılaştırmak istedik" ifadeleriyle güneş ve gölge ortamları tartışmaya açılmıştır. Tartışmadaki diğer bir görüş ise,

OÖ55 "Termometreyi ilk olarak kuma gömerek sıcaklığı tespit ettik. Daha sonra gölge ve güneşte ayrı ayrı ölçümler alınarak aritmetik ortalaması bulunur, bu değer havanın gerçek sıcaklığıdır", $00 ̈ 31$ "sıcaklık ölçümlerini, güneş ışınların etki ettiği yer ve gölgede yaparak, ortalamasını aldık",

ifadeleri ile sıcaklık ölçümlerini gölge-güneş ve kum içerisinde ortamlarda ölçülmesi gerektiği tartışılmıştır. Öte yandan tartışma ortamında sorgulanan bir diğer nokta 
termometrenin konumudur. 0Ö3 “yukarı çıkıldıkça güneșe yaklaşıldığından, hava sıcaklığı yükselir. Bu yüzden yerde ölçüm yaptık" ifadeleri ile yere yakın ölçümü tartışılmıştır.

Ortaokul öğrencilerinin termometrede olması gereken özellikler ile ilgili sorulara verdikleri cevaplarda, içerisinde kullanılan sıvının türü üzerinde yoğunlaştığı görülmüştür. Termometre içerisinde yer alan sıvının türü sorulduğunda gelen cevapların büyük bir kısmı termometrelerde su, cıva ve alkol kullanıldığı, ancak bazı öğrencilerin suyun kullanılmaması gerektiğini belirtmişlerdir. Sekizinci sınıf öğrencisi 0Ö61 "termometre içerisinde bulunan cıva; ISI aldığında çabuk yükselen, ısı verdiğinde ise çabuk alçalan sıvı olduğu için kullanılır." șeklinde ifade etmiştir. Aynı öğrenciye "biri $110^{\circ} \mathrm{C}$ diğeri $360^{\circ} \mathrm{C}$ ölçebilen iki farklı termometre içerisinde bulunan sıvıların cıvadır, bu durumu nasıl açıklanabilir?" sorulduğunda;

00̈61"aynı ebattaki iki termometreden $360^{\circ} \mathrm{C}$ ölçebilenin içerisinde yer alan cıva 110

${ }^{\circ} \mathrm{C}$ ölçebilen termometredeki clvaya göre daha yoğundur."00̈81 "Termometrenin hassas olabilmesi için cıva kullanılmalıdır."

Buna karşın cıva yerine farklı sıvılarda kullanılabileceğini belirten ifadelerde, ortaokul öğrencilerinde yer almaktadır.

0Ö32 "sıcaklığı cıvalı termometreler ölçerken, soğuk yerlerde alkollü termometreler kullanılır. 00̈11 "Termometreye gida boyası ile renklendirilmiş su veya alkolde kullanılabilir." Dikkat çeken bir diğer ifade ise $00 ̈ 52$ "termometre içerisinde su olursa akar." 0Ö21 "Termometrelerde cıva ve alkolün her ikisi de kullanılabilir. Su kullanılmaz. Çünkü su donduğunda genleșir." 00̈78 "Termometrelerde su buharlaștığı için kullanılmaz"

Ortaokul öğrencilerinin cevapları incelendiğinde termometrede kullanılan sıvının türü, termometrenin yapısı ve ölçmenin güvenirliliğine ilişkin çoklu ve farklı termometreler kullanılarak ölçümler öne çıkmaktadır.

\section{Sıcaklığın Ölçümünden Yola Çıkarak Fen Bilgisi Öğretmen Adayları ve Ortaokul Öğrencilerinin Sıcaklık Kavramına İlişsin Düşüncelerinin Karşılaştırılması}

Sıcaklığın ölçümünden yola çıkarak fen bilgisi öğretmen adayları ve ortaokul öğrencilerinin sıcaklık kavramına ilişkin düşüncelerinin benzerlik ve farklılıkları Tablo 5'de karşılaştırılmıştır.

Tablo 5. Öğretmen adaylarının ve ortaokul öğrencilerinin sıcaklık kavramına ilişkin düşüncelerinin karşılaștırılmasına ilișkin bulgular

\begin{tabular}{|c|c|c|c|}
\hline & Temalar & $\begin{array}{c}\text { Öğretmen Adaylarının } \\
\text { Kodları }\end{array}$ & $\begin{array}{c}\text { Ortaokul Öğrencilerinin } \\
\text { Kodları }\end{array}$ \\
\hline \multirow{3}{*}{ 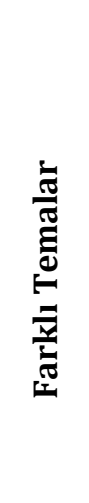 } & Termometrenin Kullanım Şekli & $\begin{array}{l}\text { Termometreyi } \\
\text { yalıtkan bir madde ile } \\
\text { asarak sabitlemek } \\
>\quad \text { Termometre yatay } \\
\text { tutmak }\end{array}$ & $\begin{array}{l}\text { Birden çok ölçüm } \\
\text { yapmak } \\
>\begin{array}{l}\text { Farklı termometre } \\
\text { kullanmak }\end{array}\end{array}$ \\
\hline & $\begin{array}{l}\text { Hava Sıcaklığının Ölçüldüğü } \\
\text { Ortam }\end{array}$ & $>$ Rüzgarda & --- \\
\hline & Termometrenin Yapısı & $\begin{array}{l}\text { Termometrede } \\
\text { kullanılan sıvinın } \\
\text { rengi }\end{array}$ & --- \\
\hline \multirow[b]{2}{*}{ 离 } & Termometrenin Kullanım Şekli & $\begin{array}{l}\text { Termometreyi dik } \\
\text { tutmak }\end{array}$ & $\begin{array}{l}\text { Termometreyi dik } \\
\text { tutmak }\end{array}$ \\
\hline & $\begin{array}{l}\text { Hava Sıcaklığının Ölçüldüğü } \\
\text { Ortam }\end{array}$ & $\begin{array}{ll}> & \text { Termometrenin } \\
& \text { yerden yüksekliği } \\
& \text { Önce gölge sonra } \\
& \text { güneşli ortamda }\end{array}$ & $\begin{array}{l}\text { Termometrenin } \\
\text { yerden yüksekliği } \\
\text { Önce gölge sonra } \\
\text { güneşli ortamda }\end{array}$ \\
\hline
\end{tabular}




\begin{tabular}{llll}
\hline & ölçüm ve ortalaması & ölçüm ve ortalaması \\
\cline { 2 - 4 } & $>\begin{array}{l}\text { Termometrede } \\
\text { Termometrenin Yapısı }\end{array}$ & $>\begin{array}{l}\text { Termometrede } \\
\text { kullanılan } \\
\text { türülan sı̈ının }\end{array}$ \\
\hline
\end{tabular}

Tablo 5'de yer alan bulgular incelendiğinde öğretmen adayları ve ortaokul öğrencilerinde dört benzer kod yer almıştır. Ortaokul öğrencilerinin yalnız termometrenin kullanım şekli temasında iki farklı kod yer almıştır. Bu kodlar öğretmen adaylarına göre daha kavram yanılgısı içermemektedir. Hava sıcaklığının ölçüldüğü ortam ve termometrenin yapısı temalarında ortaokul öğrencilerinin, öğretmen adaylarından farklı kodları oluşmamıştır.

\section{Fen Bilgisi Öğretmen Adayları ve Ortaokul Öğrencilerinin Tasarladıkları Termometrelerin Nitelikleri İlişsin Bulgular}

Araştırmada gönüllü 35 ortaokul öğrencisi ile 46 fen bilgisi öğretmen adaylarının tasarladıkları termometrelerin nitelikleri (Termometre gerçeğe ne kadar yakın?; Termometre hangi ilkeye göre tasarlanmış?; Termometre hangi maddelerin sıcaklığını ölçüyor?; Termometrenin tasarımı ve işlevselliği nasıl?) ürün değerlendirme ölçeği ile değerlendirilmiștir.

\section{Termometre gerçeğe ne kadar yakın? alt bölümüne ilişkin bulgular}

Katılımcıların termometrelerde temel altı fiziksel özelliğin değişmesi durumunda sıcaklıklarının ölçümüne ilişkin tasarladıkları termometrenin gerçeğe yakınlığına ilişkin frekans ve yüzde değerleri Tablo 6'de sunulmuştur.

Tablo 6. Öğretmen adaylarının ve ortaokul öğrencilerinin tasarladıkları termometre gerçeğe ne kadar yakın? bölümüne ilişkin bulgular

\begin{tabular}{|c|c|c|c|c|c|c|c|c|}
\hline \multirow{4}{*}{ Madde } & \multicolumn{8}{|c|}{ Frekans } \\
\hline & \multicolumn{4}{|c|}{ Öğretmen Adayı } & \multicolumn{4}{|c|}{ Ortaokul Öğrencisi } \\
\hline & \multicolumn{2}{|c|}{ Mevcut } & \multicolumn{2}{|c|}{$\begin{array}{l}\text { Mevcut } \\
\text { değil }\end{array}$} & \multicolumn{2}{|c|}{ Mevcut } & \multicolumn{2}{|c|}{ Mevcut değil } \\
\hline & $\mathrm{f}$ & $\%$ & $\mathrm{f}$ & $\%$ & $\mathrm{f}$ & $\%$ & $\mathrm{f}$ & $\%$ \\
\hline Termometrenin ölçüm aralığı ne? & 21 & 45,7 & 25 & 54,3 & 23 & 65,7 & 12 & 34,3 \\
\hline Termometre sürekli ölçüm yapabiliyor mu? & 46 & 100 & 0 & 0 & 35 & 100 & 0 & 0 \\
\hline $\begin{array}{l}\text { Termometre ölçümü belirli bir sürede } \\
\text { yapabiliyor mu? }\end{array}$ & 46 & 100 & 0 & 0 & 35 & 100 & 0 & 0 \\
\hline Termometrenin hassasiyeti nedir? & 21 & 45,7 & 25 & 54,3 & 23 & 65,7 & 12 & 34,3 \\
\hline Termometrenin hata payı nedir? & 21 & 45,7 & 25 & 54,3 & 23 & 65,7 & 12 & 34,3 \\
\hline Termometre doğru ölçüm yapıyor mu? & 21 & 45,7 & 25 & 54,3 & 23 & 65,7 & 12 & 34,3 \\
\hline Termometrenin tutarlılığı nedir? & 46 & 100 & 0 & 0 & 35 & 100 & 0 & 0 \\
\hline
\end{tabular}

Değerlendirme formunun bu bölümünde, ölçüm aralığı ile kastedilen; sıcak-soğuk ortamda termometre üzerindeki fiziksel değişkenlerin izlenebilmesi veya aradaki farkların tespit edilebilmesi için görsel işaretler bulunmasıdır. Tablo 6'de görülüyor ki ortaokul öğrencilerinin tasarladığı termometrelerde ölçüm aralığı olanlar $(\% 65,7)$ öğretmen adaylarında görülme oranından $(\% 45,7)$ daha yüksektir. Yapılan kikare testi sonucuna göre ise ortaokul öğrencileri ile öğretmen adaylarının tasarladıkları termometreler arasında, ölçüm aralığı kriteri açısından anlamlı fark olmadığı tespit edilmiştir $\left(X^{2}=3,224\right.$ sd=1 $\left.p=0,73\right)$. Bununla ilişkili olarak, ölçüm aralığı olmayan termometrelerin; hassasiyet, hata payı ve doğru ölçüm yapma kriterleri de değerlendirilememiştir.

Termometrelerdeki ölçüm aralığı derecelendirmeleri incelendiğinde 2-10 aralığında değişmektedir. Yani termometre aralıkları 2,4,6,8 veya 10,20,30,40 gibi aralıklar ile devam etmektedir. "Termometrenin hata payı nedir" sorusu ile; hata payı hassasiyetin yarısı olduğu için 
bu madde doğrudan ilişkilidir. "Termometre doğru ölçüm yapıyor mu?" maddesinde doğru ölçümün niteliği; yapılmış olan termometrelerin sıcaklık değişimine karşı tepki vermesidir. Örneğin sıvı hacminin artması niteliği göz önünde bulundurularak yapılmış bir termometrede sıcaklık ile sıvının yükselmesi, soğuk ortamda sıvı seviyesinin alçalması anlamına gelmektedir. $\mathrm{Bu}$ kriterleri sağlayan termometreler öğretmen adaylarında 21 (\%45.7) ve ortaokul öğrencilerinde 23 (\%65.7) görülmüştür. Yapılan kikare testi sonucuna göre ise ortaokul öğrencileri ile öğretmen adaylarının tasarladıkları termometreler arasında, ölçüm aralığı kriteri açısından anlamlı fark olmadığı tespit edilmiştir $\left(X^{2}=3,224 \mathrm{sd}=1 \mathrm{p}=0,73\right)$

"Termometre sürekli ölçüm yapabiliyor mu?" maddesinde sürekli ölçümden kasıt/anlayış termometrenin on dakika içerisinde sabitlenerek ölçüm yapmasıdır. Her iki grubun termometreleri on dakika içerisinde birden çok ölçüm yapmaktadır. "Termometre ölçümü belirli bir sürede yapabiliyor mu?" maddelerinde, her iki grubunda tasarladığı termometrelerde bulunan özellik olarak görülmektedir. Her iki grubun tasarladığı termometreler birden çok ölçümü gerek sıcak gerekse soğuk ortamlara konulduğunda, termometrenin dayandığı çalışma niteliğine göre (fiziksel özellik) yaklaşık on dakika içerisinde sabitlendiği görülmüştür. Örneğin çalışma niteliği sabit basınç altındaki gazların hacim ilkesine dayanan termometrede (șekil 4a, 4b) sıcaklık farkından kaynaklanan fiziksel nitelik on dakika içerisinde sabitlenerek sıcaklık değeri okunabilmiştir.

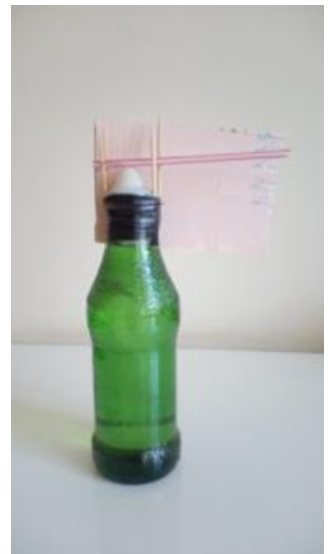

Şekil 4a. Ortaokul öğrencisi tasarımı (örnek 73)

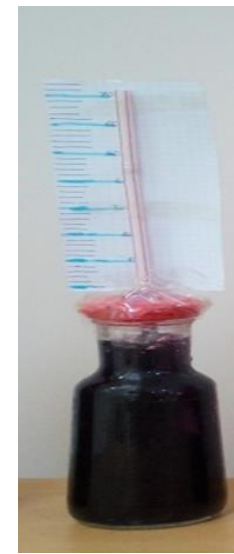

Şekil 4b. Öğretmen adayı tasarımı (örnek 28)

\section{Termometre hangi ilkeye göre tasarlanmış? alt bölümüne ilişkin bulgular}

Katılımcların termometre değerlendirme formunun termometrenin tasarlandı̆̆ ilke bölümüne ilişkin frekans ve yüzde değerleri Tablo 7'da sunulmuștur.

Tablo 7. Öğretmen adaylarının ve ortaokul ögrencilerinin tasarladıkları termometre hangi ilkeye göre tasarlanmış? bölümüne ilişsin bulgular

\begin{tabular}{lcccc}
\hline \multirow{2}{*}{ Madde } & \multicolumn{2}{c}{ Öğretmen Adayı } & \multicolumn{2}{c}{ Ortaokul Öğrencisi } \\
\cline { 3 - 5 } & $\mathrm{f}$ & $\%$ & $\mathrm{f}$ & $\%$ \\
\cline { 1 - 4 } Sivıların hacim değişimi & 46 & 100 & 25 & 71,4 \\
Katıların uzunluk değişimi & 0 & 0 & 0 & 0 \\
$\begin{array}{l}\text { Sabit hacimdeki bir gazın basınç } \\
\text { değişimi }\end{array}$ & 0 & 0 & 0 & 0 \\
$\begin{array}{l}\text { Sabit basınçtaki bir gazın hacim } \\
\text { değişimi }\end{array}$ & 0 & 0 & 9 & 25,7 \\
$\begin{array}{l}\text { Bir iletkenin elektrik direncinin } \\
\text { değiş̧imi }\end{array}$ & 0 & 0 & 1 & 2,9 \\
Çok sıcak cisimlerin renk değişimi & 0 & 0 & 0 & 0 \\
Diğer & 0 & 0 & 0 & 0 \\
\hline
\end{tabular}


Tablo 7 yer alan bulgular incelendiğinde öğretmen adaylarının tasarladı̆̆ı tüm termometreler sıvıların hacim ilişkisine dayandığı görülmektedir. Buna karşın ortaokul öğrencilerinde sıvıların hacim ilişkisine göre tasarlanan termometre yüzdesi \%71,4 iken sabit basınçtaki bir gazın hacim değişimi ilkesine göre tasarlanan termometre yüzdeliği \%25,7 (şekil 5a) ve bir iletkenin elektrik direncinin değişimine dayanan ilkeye göre tasarlanan termometre yüzdesi \%2,9 (şekil 5b) olduğu görülmüştür. Yapılan kikare testi sonucuna göre ise ortaokul öğrencileri ile öğretmen adaylarının tasarladıkları termometreler arasında, termometrenin tasarlanma ilkesi açısından anlamlı fark olduğu tespit edilmiştir $\left(X^{2}=14,994 \mathrm{sd}=2 \mathrm{p}=0,01\right)$.

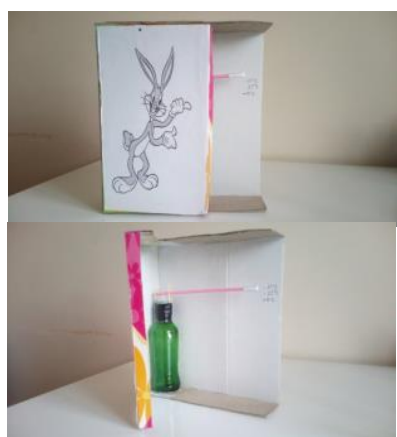

Şekil 5a. Sabit basınçtaki bir gazın hacim değişikliği ilkesi ile çalışan termometre ortaokul öğrencisi (örnek 72)

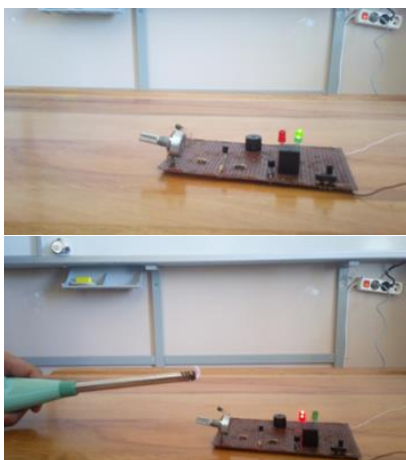

Şekil 5b. Elektrik direncinin değişimine dayanan ilkeye göre tasarlanan termometre ortaokul ögrencisi (örnek

81)

\section{Termometre hangi maddelerin sıcaklığını ölçüyor? alt bölümüne ilişkin bulgular}

Geliștirilen termometrelerin hangi maddelerin sıcaklığını ölçtüğü ortaya konulmuștur (Tablo 8). Maddenin her üç halinin sıcaklığını ölçebilen termometreler katı-sıvı-gaz șeklinde tanımlanmıștır. Yapısı ve boyutları itibariyle sadece sıvı maddelerin sıcaklığını ölçebilen termometreler sıvı olarak tanımlanırken (Şekil 6a), yapı ve boyut olarak katı ve maddelerin sıcaklığını ölçebilen termometrelere katı-gaz (Şekil 6b), sadece gazların sıcaklı̆̆ını ölçebilen termometreler (Şekil 6c) gaz olarak tanımlaması yapılmıştır. Benzer bir tanımlama maddenin sıvı ve gaz hali için sıvı-gaz (Şekil 6d), şeklinde ifade edilmiştir.

Tablo 8. Katılımcıların tasarladıkları termometrelerin hangi maddelerin sıcaklığını ölçtüğü bölümüne ilișkin bulgular

\begin{tabular}{lccccc}
\hline & Katı-Sıvı-Gaz & Sadece Gaz & Sıvı-Gaz & Sadece Sıvı & Katı-Gaz \\
\hline $\begin{array}{l}\text { Öğretmen } \\
\begin{array}{l}\text { Adayı } \\
\text { Ortaokul } \\
\text { Öğrencisi }\end{array}\end{array}$ & 40 & 4 & 1 & 1 & 0 \\
\hline
\end{tabular}

Maddelerin katı-sıvı-gaz halinde bulunmaları durumunda da tasarlanan termometreler kullanılabiliyorken; öğretmen adaylarında 4, ortaokul öğrencilerinde ise 9 termometrenin sadece gazların sıcaklığını ölçebilecek olduğu tespit edilmiştir. Yapılan kikare testi sonucuna göre ise ortaokul öğrencileri ile öğretmen adaylarının tasarladıkları termometreler arasında, termometrenin hangi maddelerin sıcaklığını ölçtüğü ilkesi açısından anlamlı fark olmadığı tespit edilmiştir $\left(X^{2}=2,115 \mathrm{sd}=1 \mathrm{p}=0,146\right)$. 


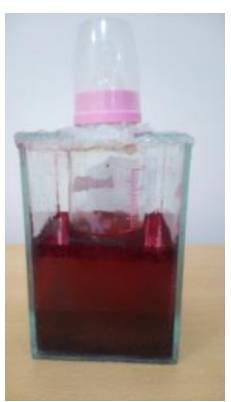

Şekil 6a. Sadece sıvı maddelerin sıcaklığını ölçebilen termometre öğretmen adayı (örnek 46)

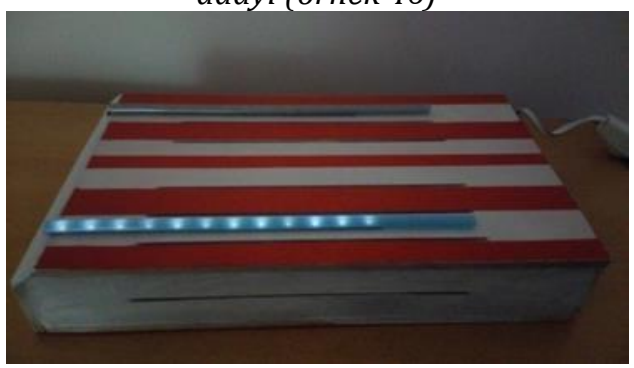

Şekil 6c. Sadece gaz maddelerin sıcaklığını ölçebilen termometre (soldaki öğretmen adayı örnek 46, sağdaki ortaokul ögrrencisi örnek 72)

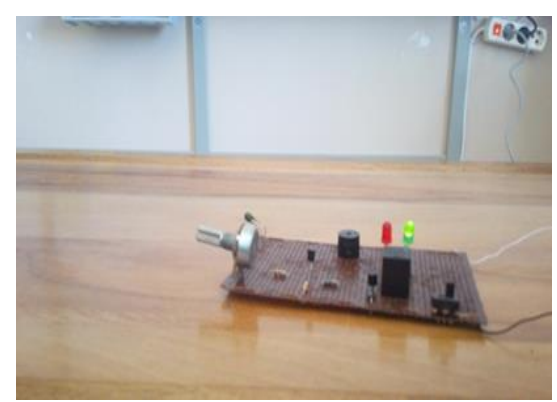

Şekil 6b. Katı-gaz maddelerin sıcaklığını ölçebilen termometre ortaokul öğrencisi (örnek 81)
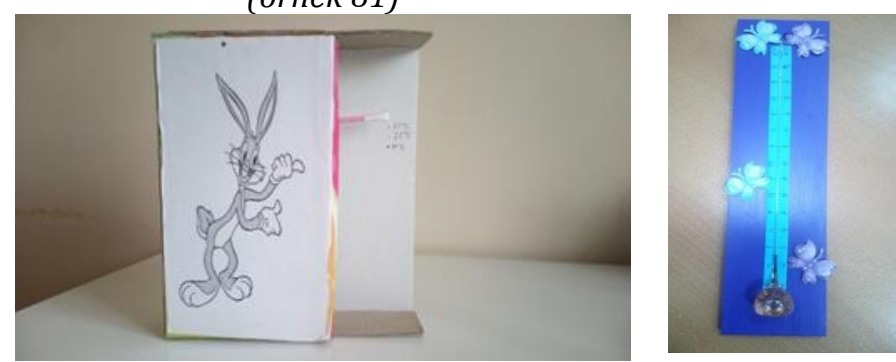

Şekil 6d. Sivigaz maddelerin sicaklığını ölçebilen termometre (öğretmen adayı örnek 41)

\section{Termometrenin tasarımı ve işlevselliği nasıl? alt bölümüne ilişkin bulgular}

Geliştirilen termometrelerin tasarımı ve işlevselliği Tablo 9'de belirtilen niteliklerde değerlendirilmiştir.

Tablo 9. Öğretmen adaylarının ve ortaokul öğrencilerinin tasarladıkları termometre hangi ilkeye göre tasarlanmıș? bölümüne ilişkin bulgular

\begin{tabular}{|c|c|c|c|c|c|c|c|c|}
\hline \multirow{4}{*}{ Madde } & \multicolumn{8}{|c|}{ Frekans } \\
\hline & \multicolumn{4}{|c|}{ Öğretmen Adayı } & \multicolumn{4}{|c|}{ Ortaokul Öğrencisi } \\
\hline & \multicolumn{2}{|c|}{ Evet } & \multicolumn{2}{|c|}{ Hayır } & \multicolumn{2}{|c|}{ Evet } & \multicolumn{2}{|c|}{ Hayır } \\
\hline & $\mathrm{f}$ & $\%$ & $\mathrm{f}$ & $\%$ & $\mathrm{f}$ & $\%$ & $\mathrm{f}$ & $\%$ \\
\hline Termometrenin maliyeti düşük mü? & 42 & 91,3 & 4 & 8,7 & 35 & 100 & 0 & 0 \\
\hline Termometre kolay kurulabiliyor mu? & 45 & 98,8 & 1 & 2,2 & 35 & 100 & 0 & 0 \\
\hline Termometre kolay taşınabiliyor mu? & 1 & 2,2 & 45 & 97,8 & 1 & 2,9 & 34 & 97,1 \\
\hline $\begin{array}{l}\text { Termometreyi bağımsız bir kullanıcı } \\
\text { kullanabilir mi? }\end{array}$ & 45 & 97,8 & 1 & 2,2 & 35 & 100 & 0 & 0 \\
\hline Termometre ilgi çekici mi? & 4 & 8,7 & 42 & 91,3 & 10 & 28,6 & 25 & 71,4 \\
\hline $\begin{array}{l}\text { Termometrenin ilgiyi sürdürebiliyor } \\
\text { mu? }\end{array}$ & 4 & 8,7 & 42 & 91,3 & 10 & 28,6 & 25 & 71,4 \\
\hline Termometre sağlam ve dayanıklı mı? & 5 & 10,9 & 41 & 81.1 & 10 & 28,6 & 25 & 71,4 \\
\hline Termometrenin kullanımı kolay mı? & 46 & 100 & 0 & 0 & 35 & 100 & 0 & 0 \\
\hline Termometrenin depolanması kolay mı? & 2 & 4,3 & 44 & 95,7 & 10 & 28,6 & 25 & 71,4 \\
\hline Termometrenin raf ömrü uzun mu? & 4 & 8,7 & 42 & 91,3 & 2 & 5,7 & 33 & 94,3 \\
\hline
\end{tabular}

Termometre maliyetleri değerlendirilmesinde piyasada satılan termometre fiyatlarından yararlanılmıştır. Termometre fiyatları özellik, üretimi için ayrılan zaman, kalite, işçilik ve markasına göre $10 \mathrm{TL}$ ile $350 \mathrm{TL}$ arasında değişmektedir. Bu çalışmada ortalama 50 TL üstünü 
maliyeti yüksek olarak değerlendirmede bulunduk. Yaplan kikare testi sonucuna göre ise ortaokul öğrencileri ile öğretmen adaylarının tasarladıkları termometreler arasında, termometrenin maliyeti açısından anlamlı fark olmadığı tespit edilmiştir $\left(X^{2}=3,202 \mathrm{sd}=1 \mathrm{p}=\right.$ 0,074).

Kolay kurulabilme özelliği ile aranan kriter; termometre tasarlama ve kurgulanması aşamasında gereken zaman ve emek kolaylığıdır. Kolay taşınabilme ile ilgili aranan koşulda; termometrelerin hacim, kütle, boyut gibi özelliklerin yanı sıra termometreyi koruyucu bir dış yüzeyin bulundurması taşınma sırasında görebileceği muhtemel zararları engelleyecektir. Bu madde ile ilgili Şekil 7'de kolay kurulamayan ve taşınamayan bir termometreye örnek gösterilmiştir. Yapılan kikare testi sonucuna göre ise ortaokul öğrencileri ile öğretmen adaylarının tasarladıkları termometreler arasında, termometrenin kolay kurulabilme ve taşınabilme açısından anlamlı fark olmadığı tespit edilmiştir $\left(X^{2}=0,770 \mathrm{sd}=1 \mathrm{p}=0,380 ; X^{2}=\right.$ $0,039, \mathrm{sd}=1 \mathrm{p}=0,844)$.

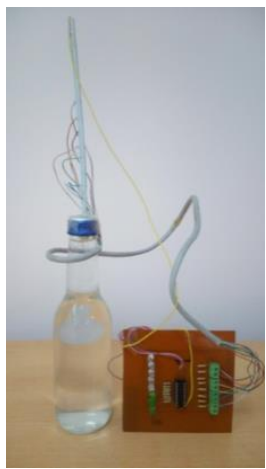

Şekil 7. Kolay kurulamayan ve taşınamayan termometre (öğretmen adayı örnek 43)

Geliştirilen termometrelerde ilgiyi çekme ve ilgiyi sürdürebilmede aranan nitelik kişide; çalışmasından yapımına kadar, kullanımından alternatif modellerinin üzerinde düşünmeye kadar merak duygusunu uyandırmak ve merak duygusunu sürdürebilmektir. Ayrıca ilgi çekici bir termometreyi farklı mekân ve koşullarda deneme isteği uyandırması ilgiyi sürdürebildiği şeklinde yorumlanmıştır. Yapılan kikare testi sonucuna göre ise ortaokul öğrencileri ile öğretmen adaylarının tasarladıkları termometreler arasında, termometrenin ilgiyi çekme ve ilgiyi sürdürme özelliği açısından anlamlı fark olduğu tespit edilmiştir $\left(X^{2}=5,492 \mathrm{sd}=1 \mathrm{p}=\right.$ 0,019).

Termometrelerde sağlam ve dayanıklılık maddesi ile farklı mekân ve kullanıcılılarda birden çok ölçüm sonunda termometreden parça kopması, dağılması deforme olması gibi nedenlerle kullanılamaz hale gelmesi kastedilmiştir. Öğretmen adaylarında bu koşulu sağlayan 5 termometre $(\% 10,9)$, ortaokul öğrencilerinde ise 10 termometre $(\% 28,6)$ geliştirilmiștir. Yapılan kikare testi sonucuna göre ise ortaokul öğrencileri ile öğretmen adaylarının tasarladıkları termometreler arasında, termometrenin sağlamlık ve dayanıklılık özelliği açısından anlamlı fark olduğu tespit edilmiştir $\left(X^{2}=4,128 \mathrm{sd}=1 \mathrm{p}=0,042\right)$.

Termometrelerin depolanma özelliği için aranan kriterde saklama koşullarındaki raf düzeni, sıcaklık, nem, ışık ve termometrenin geometrik şekli gibi özel koşullar dikkate alınmıştır. Yapılan kikare testi sonucuna göre ise ortaokul öğrencileri ile öğretmen adaylarının tasarladıkları termometreler arasında, termometrenin depolanma özelliği açısından anlamlı fark olduğu tespit edilmiştir $\left(X^{2}=9,242 \quad s d=1 \mathrm{p}=0,002\right)$. Raf ömrü depolanma kolaylığı ile paralellik göstermektedir. Aşağıdaki şekilde saklanması kolay olmayan termometrelere örnekler verilmiştir (Şekil 8). 

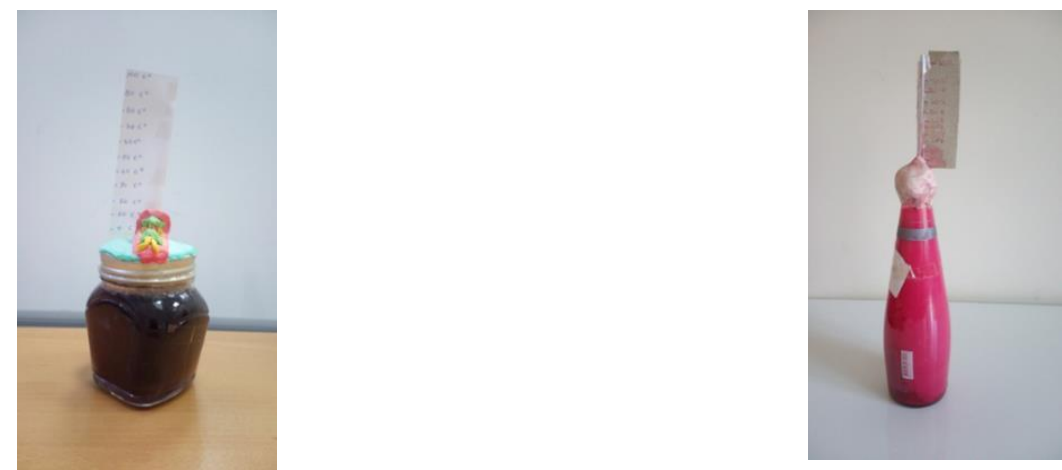

Şekil 8. Depolanması kolay olmayan (solda öğretmen adayı örnek 02, sağda ortaokul öğrencisi örnek 60)

Sonuç olarak, her iki grupta da termometrenin maliyeti, kolay kurulabilirliği, bağımsız bir kullanıcı tarafından kullanılabilmesi, ilgiyi çekmesi-sürdürebilmesi, sağlamlılık-dayanıklılık, depolanması maddelerinde ortaokul öğrencilerinin öğretmen adaylarına göre daha yüksek olduğu söylenebilir. Özellikle ortaokul öğrencilerinin tasarladıkları termometrelerin ilgiyi çekmede, sürdürmede, depolama, sağlam ve dayanıklılıkta daha yüksek olduğu dikkat çekicidir.

\section{TARTIŞMA, SONUÇ ve ÖNERILER}

Bu bölümde, araştırmadan elde edilen bulgular alan yazın ile karşılaştırılarak tartışılmış ve yorumlanmıștır. Sonrasında gelecekte planlanan araştırmalara ışık tutabilmek adına öneriler sunulmuştur.

\section{Tartışma}

$\mathrm{Bu}$ araştırmada sıcaklık ölçümünden yola çıkarak sıcaklık kavramının sorgulanması neticesinde elde edilen bulgular tartışılmıştır. Bu başlık iki bölümden oluşmaktadır. İlk bölüm hava sıcaklığının ölçülmesi etkinliği ile fen bilimleri öğretmen adayları ve ortaokul öğrencilerinde sıcaklık kavramına ilișkin ortaya çıkan çelişkiler değerlendirilmiştir. İkinci bölümde ise sıcaklığın madde üzerinde meydana getirdiği fiziksel parametrelere bağlı olarak ortaokul öğrencileri ve öğretmen adayları tarafından tasarlanan termometre ürünlerinin karşılaştırılması yer almaktadır.

\section{Hava sıcaklığının termometre ile ölçülmesi sonucunda oluşan çelişkilere ilişkin tartışma}

Ortaokul öğrencilerinin hava sıcaklığının ölçülmesi etkinliği ile çekici ve uyarıcı bir etki oluşturarak, sıcaklık kavramını sorgulamaları sağlanmıştır. Bu bölümde hava sıcaklığının ölçülmesi etkinliği ile fen bilgisi öğretmen adaylarının ve ortaokul öğrencilerinin sıcaklık kavramına yönelik ön bilgileri ortaya çıkarılmış, benzerlik ve farklılıklar karşılaştırmalı olarak tartışılmıştır. Araştırma sonucunda elde edilen bulgular incelendiğinde öğretmen adaylarının ve ortaokul öğrencilerinin sıcaklık kavramına ait ön bilgileri arasındaki farklar termometrenin kullanım şekli, hava sıcaklığının ölçüldüğü ortam ve termometrenin yapısı temalarında farklı kodlarla yer almaktadır.

Termometrenin kullanım şeklinde dik tutma kodu altında yer alan çelişkiler şunlardır; yerçekimi, termometredeki sıvının yer değiștirmesi, termometrenin tüm yüzeyinin sıcaklığa karşı duyarlı olması ve güneș ışığını alış açısı. Hava sıcaklığını ölçerken ortaokul öğrencileri tarafından termometreyi dik ve yatay tutmalarının nedeni; her iki durumda da sonucun değişip değişmediğini gözlemlemek olduğu ifade edilmiştir. Ölçme aracı olan termometreyi dik ya da yatay tutmanın sorgulanması ile herhangi bir kavram çelişkisine yol açmadığı görülmüştür. Diğer taraftan fen bilgisi öğretmen adayları termometreyi dik tutmalarının nedenini yerçekimine, yatay tutulması durumunda termometre içerisinde yer alan sıvının farklı hareket edeceğine, termometre ile teması en aza indirme ve güneş ışınlarının geliş açılarına bağladıkları görülmüştür. Böyle bir çelişkinin ortaya çıkması bazı hassas kavramların özellikle sıcaklık, ısı, 
enerji ve yerçekimi konularda ön bilgilerden kaynaklandığı düşünülebilinir (Karakuyu, 2006; Çekiç, 2004).

Fen bilgisi öğretmen adaylarında termometrenin kullanım şekli temasında yer alan termometreyi yalıtkan bir madde ile asma ve termometreyi yatay tutma kodu ortaokul öğrencilerinde yer almamıştır. Diğer taraftan araştırmanın bulgularında yer alan termometrenin kullanım şekli temasında, havanın sıcaklığını ölçme işlemini birden çok ölçüm yapma ve farklı termometreler kullanma kodları ortaokul öğrencilerinde yer alırken fen bilgisi öğretmen adaylarında yer almamaktadır. Bu sonuç, Yürümezoğlu ve Oğuz (2009)'un çalışmasında yer aldığı gibi çocukların yetişkinlere göre daha az bilimsel bilgi ve en önemlisi kavram yanılgılarının azlığı ile daha nitelikli/sade akıl yürütebildiklerini, sistemli ve değişkenli düşünmeyi deney sırasında elemine edebilmeyi başarabildiklerini göstermektedir.

Havanın sıcaklığının ölçüldüğü ortam temasında, termometrenin yerden yüksekliği ve önce gölge sonra güneşli ortamda ölçüm yapılarak ortalamanın alınması kodları fen bilgisi öğretmen adayları ve ortaokul öğrencileri için ortaktır. Benzer şekilde Korkmaz ve Kaptan (2002)'ın çalışmasında da öğrenciler güneşin sıcaklık yaydığını veya sıcaklığın bir enerji çeşidi/ş̧ekli (Korkmaz ve Kaptan, 2002; Bayram, 2010) olduğu ifade edilmiştir. Diğer taraftan rüzgar kodu sadece öğretmen adaylarında görülmektedir. Bu durum bilimsel süreç becerilerinde yer alan değişkenleri belirleme, değişkenleri değiştirme ve kontrol etmenin önemini tartışmasız ortaya koymaktadır. Ateş (2005)'in çalışmasında belirttiği gibi; bilimsel bir çalışmada önemli bir yere sahip olan değişkenleri belirleme ve kontrol etme konusunda kullanılan bağımlı-bağımsız değişkenlerin önemini ortaya çıkarmıştır. Bir başka ifade ile çalışma sonucunu etkileyecek veya etkilemesi muhtemel diğer bütün değişkenlerin tespit edilmesinin önemini ortaya çıkarmıştır.

Termometrenin yapısı temasında termometrede kullanılan sıvının türü çok tartışılmıştır. Ortaokul öğrencileri ile fen bilgisi öğretmen adaylarında termometredeki sıvının cıva yada alkol olması gerekliliğini; daha hassas ölçüm yapabilmeleri şeklinde açıklamışlardır. Ortaokul öğrencilerinin suyu kullanmama nedeni olarak suyun donduğunda hacminin artması şeklinde ifadelendirmiştir. Aynı soruya fen bilgisi öğretmen adaylarının geliştirdiği açıklamada; su kullanılması durumunda termometrenin boyunun uzamasına neden olacağını ifade ederek termometre yapısını basınçla ilişkilendirmiștir. Öğretmen adaylarının eğitim yaşantıların ilk dönemlerinde suyun deniz seviyesinde kaynama noktasının değişimi açık hava basıncı ile açıklanmıştır. Ancak bu durum öğrencilerin sıcaklık ve basınç kavramlarını birbiri ile ilişkilendirerek açıklamaya çalışmalarına yol açmış olabilir. Bilgi edinimi önceden var olan kavramlarla başladığı düşünülürse bu ilişkilendirme Yağbasan ve Gülçiçek (2003)'in ifade ettiği gibi; öğrencilerin formal fen derslerine katılmadan önceki bilgi birikimleri ve olguları algılama şekillerinin önemini ortaya koymuştur.

Sonuç olarak, sıcaklığın nasıl ölçülebildiğinden yola çıkarak sıcaklık kavramının tanımlanabileceği; bunun için de sıcaklığın maddenin fiziksel durumlarına bağlı olduğu öğrencilerce bir etkinlik dâhilinde denenmiştir. Farklı türde termometrelerin dayandığı çalışma prensibi; sıcaklığın sıvının genleşmesini sağladığı, sabit basınçtaki gazın hacim değişikliği ve bir iletkenin elektrik direncinin değişimi gibi fiziksel parametreler öğrencilerce gözlenmiştir. Benzer şekilde, Young, Freedman ve Ford (2008)'a göre sıcaklık, maddeye ait moleküllerin kinetik enerjisine bağlıdır. Bu durum sıcaklık kavramını ısı ile karmaşık bir ilişki içerisine sokmaktadır. Bu yüzden sıcaklığı açıklamak için iyi bir giriş olmayacaktır. Sıcaklık moleküler düzeye inilmeden de tanımlanabilir. Çünkü sıcaklık maddenin fiziksel durumuna bağlıdır. Buna karşın Radtka (2013) çalışmasında; 1950'li yıllarda İngiltere'de yayımlanan ders kitaplarında ısının biyolojik yapılanmasını da içermektedir (sıcakkanlı ve soğukkanlı hayvanlar arasındaki farklar, kışın sıcaklığı koruma stratejileri gibi). 21. yüzyıl İngiliz ders kitaplarında ısı ile ilgili çalışmalara özel bir bölüm ayırmaktadır. Ayrıca sıcaklığında yer aldığı ve maddenin parçacık modelini içeren bölümler yer almaktadır.

\section{Tasarlanan termometrelerin niteliklerine ilişkin tartışma}

Dorris (1991)'e göre öğrencilerin bilimsel kavramları anlama ve kullanma becerilerini anlamak için öğrenci etkinlikleri birçok açıdan incelenmesi gerekir. Bu açıdan öğrencilerin bilimsel deneyimleri gözlemlenmelidir (Akt: Korkmaz ve Kaptan, 2002). Bu açıdan araştırmada 
ortaokul öğrencileri ile fen bilgisi öğretmen adaylarının tasarladıkları ürünler değerlendirilmiştir. Ortaokul öğrencilerinin tasarladığı termometrelerde termometre değerlendirme formunda; ölçüm aralığı, hassasiyet, hata payı ve doğru ölçüm yapma kriterlerinde öğretmen adaylarına göre anlamlı fark olmamasına rağmen daha başarılı oldukları tespit edilmiştir. Bu durum Yürümezoğlu ve Oğuz (2009)'un belirttiği gibi sorgulama temelli bilim eğitimi çerçevesinde işlenen derslerde etkinlikler doğru bir rehberlik ile yüksek katılımcı ortamlarda yapıldığında çocukların en az yetişkinler kadar başarı gösterdikleri daha az zihinsel karmaşalara maruz kaldığı ifadesi ile örtüşmektedir. Bir başka çalışmada Korkmaz ve Kaptan (2002), bilimsel kavramları anlama ve kullanma açısından öğrenci ürünleri incelendiğinde ilköğretim öğrencilerin bilimsel kavramları yansıtarak ürün geliştirdiklerini ifade etmişlerdir.

Termometre değerlendirme ölçeğinin, "Termometre Hangi Illkeye Göre Tasarlanmıș" alt bölümünde yer alan bulgularda; fen bilgisi öğretmen adaylarının tasarladıkları termometrelerinin tamamı sıvıların hacim değişimi ilkesine göre oluşturulmuştur. Buna karşın ortaokul öğrencilerinin tasarladıkları termometrelerde sıvıların hacim değişimi ilkesinin dışında sabit basınçtaki bir gazın hacim değişikliği ile bir iletkenin elektrik direncinin değişimi ilkelerine dayanan ürünlerde oluşturulmuştur.

Termometrenin Hangi Illkeye Göre Tasarlanmış alt bölümünde yer alan termometrenin kullanım kolaylığı kriteri hariç diğer kriterlerde veriler farklılaşmaktadır. Termometrenin maliyeti, kolay kurulabilmesi ile taşınabilmesi, termometrenin bağımsız bir kullanıcı tarafından kullanabilme ve raf ömürleri kriterleri açısından ortaokul öğrencileri fen bilgisi öğretmen adaylarından daha iyi durumdadır. Termometrenin ilgiyi çekmesi, sürdürmesi, sağlam ve dayanıklılık ile depolanma özellikleri kriterleri açısından anlamlı fark tespit edilmiştir. Sorgulamaya dayalı öğrenme ortamları, öğrencilerin fen ve teknoloji okur-yazarı olabilmeleri için, araştırma süreçlerine uygun olarak düşünmeyi öğrenebilmeleri ve bu süreçlere ilişkin davranış geliştirebilmeleri noktasında gerekli olabilecek her türlü alt yapıya sahiptir (Duban, 2008). Çocuklar, çevrelerine meraklı gözlerle bakan küçük birer bilim adamı gibidirler. Çevrelerine ilgi duyarlar, gözlemledikleri olayların nedenlerini merak ederler ve bunlara anlam vermeye çalışırlar. Bu çabalar neticesinde, çeşitli düşünceler üretir (Laçin-Şimşek ve Tezcan, 2008) olmaları bu farkı açıklayabilir.

\section{Sonuç}

Sıcaklık kavramına ilişkin bu çalışmada öğretmen adaylarının en çok termometrenin kullanım şekli, hava sıcaklığının ölçüldügü ortam ve termometrenin yapısı temalarında verdikleri cevaplarda çelişkiler görülmüştür. $\mathrm{Bu}$ çelişkiler termometrenin kullanım şekli temasinda; termometreyi yalıtkan bir madde ile asarak sabitlemek ve termometreyi yatay tutmak kodunda yoğunlaşmıştır. Termometreyi yalıtkan bir madde ile asarak sabitlemenin nedenini yerçekimine bağladıkları görülmüştür. Yine aynı temada yer alan yatay tutma durumunu güneş ışıklarının geliş açısına bağladıklarını ifade ederek önceki öğrenim hayatlarında edindikleri bilgileri termometrenin kullanım temasına uyarlamakta yanılgıya düşmüşlerdir. Hava sıcaklığının ölçüldüğü ortam temasında yer alan rüzgar kodu ile termometrenin yapısı temasında yer alan termometrede kullanılan sıvının rengi kodu ortaokul öğrencilerinde yer almadı̆̆ görülmüştür. Bu sonuçlar bize termometreyi kullanırken, hava sıcaklığının hangi ortamlarda ölçülmesi gerektiğinden ve termometrenin yapısı ile ilgili kavramları anlamada öğretmen adayları ortaokul öğrencilerine göre daha çok zorlandığını göstermiştir.

Ortaokul öğrencilerinin termometrenin kullanım şekli temasında; birden çok ölçüm yapması, farklı termometre kullanması yada sonuçlarını arkadaşları ile karşılaştırması sorgulama temelli bilim eğitiminin çocukların üzerinde kavram çelişkilerini azalttığını ortaya çıkarmıştır. Bir diğer ifade ile sıcaklık kavramının ısı kavramından bağımsız sorgulama temelli bilim eğitimi ile sıcaklığın ölçümünden yola çıkarak anlatılması, çocuklarda sıcaklığın öğretimi açısından kavram çelişkilerini önleyebileceğini göstermiştir. Çocukların, öğretmen adaylarına göre ön bilgilerinin daha kısıtlı olması nedeni ile kavramlara ön yargılı yaklaşmadıkları, 
çocukların doğası gereği öğrenmeye ve sorgulamaya daha yatkın oldukları için kavramları sorgulayarak öğrenmeye yetişkinlere göre daha yatkın olduğu düşünülebilir.

Öğrencilerin termometre tasarımları değerlendirildiğinde termometre gerçeğe ne kadar yakın alt bölümünde ölçüm aralığı, hassasiyeti, hata payı ve doğru ölçüm yapma oranı maddelerinde anlamlı fark bulunmasa da ortaokul öğrencileri, öğretmen adaylarına göre daha iyi durumdadır. Değerlendirme formun ikinci bölümü olan Termometre Hangi Illkeye Göre Tasarlanmış alt bölümünde çocukların tasarladıkları ürünler 3 ayrı çeşit iken yetişkinler tek çeşit ürün tasarlamışlardır. Değerlendirme formun dördüncü bölümü olan Termometrenin Tasarımı ve İşlevselliği Nasıl bölümünde yer alan termometrenin maliyeti, kolay kurulabilirliği, bağımsız bir kullanıcı tarafından kullanılabilmesi, ilgiyi çekmesi-sürdürebilmesi, sağlamlılıkdayanıklılık, depolanması maddelerinde ortaokul öğrencilerinin öğretmen adaylarına göre daha yüksek oranda başarılı oldukları görülmüştür. Bu sonuçta, çocukların yetişkinlere göre ürün oluştururken yaratıcılıklarının daha çeşitli olduğu gözlenmiştir.

Öğrenilen bilgilerin bir ürüne dönüştürülmesi kavramların daha iyi anlaşılmasını ve sorgulanmasını sağlamaktadır. Ayrıca kavram yanılgılarının giderilmesinde sonuç odaklı değerlendirmeden ziyade süreç odaklı değerlendirmeyi sağlamaktadır. Çocukların doğası gereği STBE'ne daha yatkın olması, yetişkinlerin önceki bilgi ve deneyimlerinin öğretim sürecine daha çok müdahil olması nedenler arasında olabilir. Ancak șu da bir gerçek ki okul dışında da kavramların yerinde kullanılmasına gayret göstermeliyiz (Șekil 9).
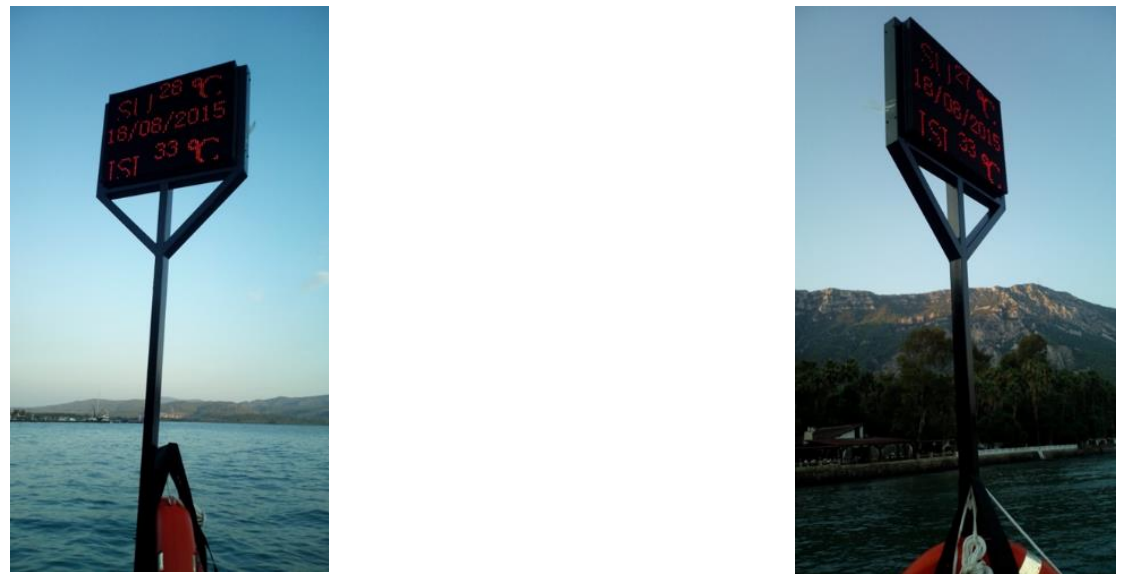

Şekil 9. Plajlarda deniz suyu sıcaklığının ısı olarak adlandırılması

\section{Öneriler}

Araştırmadan elde edilen sonuçlar ışığında aşağıda önerilen araştırmalar planlanmaktadır.

1. Ders kitaplarında ısı ve sıcaklık konularının enerji ve maddenin fiziksel özellikleri bölümlerinde ayrı ayrı işlenmesi.

2. Sıcaklık kavramının ölçümü üzerinden öğrencilere aktarılması.

3. Çalışmanın farklı katılımcılar ile de gerçekleştirilmesi.

4. Çalışmanın kütle-ağılık, elektrik, ses, ışık, sıvıların kaldırma kuvveti gibi diğer fen bilimleri kavramlarına uyarlanması.

5. Fen Bilimleri'nde yer alan farklı konulara ait ürün değerlendirme araçlarının geliştirilebilmesi.

6. STBE'nin Türkçe, matematik, sosyal bilimler gibi diğer disiplinlere uyarlanabilmesi.

7. Termometre temalı bilim şenliklerinin geliștirilebilmesi.

8. Fen bilimlerinde kullanılan ölçme araçlarına yönelik ürün sergilerin düzenlenebilmesi. 


\section{Kaynakça}

Agalday, M., Akçam, H. K., İpek, İ. ve Kablan, F. (2014) İlköğretim 4 Fen ve Teknoloji Ders ve Öğrenci Çalışma Kitabı 1. Kitap (5. Baskı), (Edit. Leblebicioğlu, G.), MEB, Ankara.

Ateș, S. (2005) Öğretmen Adaylarının Değișkenleri Belirleme ve Kontrol Etme Yeteneklerinin Geliștirilmesi, G.Ü. Eğitim Fakültesi Dergisi, 25(2), 21-39

Aydın, Z. (2007) Isı ve Sicaklık Konusunda Rastlanan Kavram Yanılgıları ve Bu Kavram Yanılgılarının Giderilmesinde Kavram Haritalarının Kullanılması, Yayımlanmamış Yüksek Lisans Tezi, Yüzüncü Yıl Üniversitesi, Fen Bilimleri Enstitüsü: Van.

Aydoğan, S., Güneş, B. ve Gülçiçek, Ç. (2003) Isı ve Sıcaklık Konusunda Kavram Yanılgıları, G.Ü. Eğitim Fakültesi Dergisi, 23(2), 111-124.

Başer, M. (2006). Fostering conceptual change by cognitive conflict based instruction on students' understanding of heat and temperature concepts, Eurasia J. Math. Sci. \&Tech. Ed, 2(2), 96-114.

Başer, M. ve Çataloğlu, E. (2005). Kavram Değişimi Yöntemine Dayalı Öğretimin Öğrencilerin Isı ve Sıcaklık Konusundaki "Yanlış Kavramlar"ının Giderilmesindeki Etkisi. Hacettepe Üniversitesi Eğitim Fakültesi Dergisi, 29, 43-52.

Başer, M. ve Geban, Ö. (2007). Effectiveness of conceptual change instruction on understanding of heat and temperature concepts, Research in Science\&Technological Education, 25(1), 115-133.

Bayram, A. (2010). Probleme Dayalı Öğrenme Yönteminin İlköğretim 5. Sinı Öğrencilerinin Fen ve Teknoloji Dersi "Isı ve Sicaklı" Konusunda Sahip Oldukları Kavram Yanılgılarını Gidermede Etkisi, Yayımlanmamış Yüksek Lisans Tezi, Selçuk Üniversitesi, Eğitim Bilimleri Enstitüsü: Konya.

Bayram, G. ve Kibar, F. S. (2014). Ortaokul Fen Bilimleri 5. Sinıf, (Edit. Karaca, Ö.), Sevgi Yayınları, Ankara.

Bell, R. L., Smetana, L., \& Binns. l. (2005). Simplifying Inquiry Instruction: Assessing the Inquiry Level of Classroom Activities. Science Teacher, 72(7), 30.

Bell, R., Blair, L., Lederman, N. G., \& Crawford, B. (2003). Just do it? Impact of a science apprenticeship on high school students' understanding of the nature of science and scientific inquiry. Journal of Research in Science Teaching, 40(5), 487-509.

Bolat, M., Aydoğdu, Y. ve Evgi, İ. (2013). Ortaöğretim Fizik 9 Ders Kitabı, Mega Yayıncılık, Ankara.

Buluş-Kırıkkaya, E ve Güllü, D. (2008). İlköğretim Beşinci Sınıf Öğrencilerinin Isı - Sıcaklık ve Buharlaşma Kaynama Konularındaki Kavram Yanılgıları, İlköğretim Online, 7(1), 15-27.

Bybee, R. W. (2006). Scientific inquiry and science teaching. In L. B. Flick \& N. G. Lederman (Eds.), Scientific Inquiry and Nature of Science (pp. 1-14). Nederlands: Springer.

Challoner, J. (2005). Popüler Bilim Kitapları Başvuru Kitaplığı Fizik, 9. Baskı, TÜBİTAK, Yayınları, Ankara.

Challoner, J. (2006). Popüler Bilim Kitapları Başvuru Kitaplığı Kimya, 8. Baskı, TÜBİTAK Yayınları, Ankara.

Cuevas, P., Lee, O., Hart, C., \& Deaktor, R. (2005). Improving science inquiry with elementary students of diverse backgrounds. Journal of Research in Science Teaching, 42, (3), 337-357.

Çekiç, S. (2004) Lise 1. Sinıf Öğrencilerinin "Isı ve Sıcaklık" Konusu Hakkında Kavram Geliștirme Süreçlerinin Incelenmesi, Yayımlanmamıș Yüksek Lisans Tezi, Gazi Üniversitesi Eğitim Bilimleri Enstitüsü, Ankara.

Çengel, Y. A. ve Boles, M. A., (2008). Termodinamik Mühendislik Yaklaşımıyla, 5. Baskı, Çev.Ed. Ali Pınarbaşı, Güven Bilimsel, İzmir,

Çepni, S., Ayancı, H. Ş. ve Çil, E. (2012). Fen ve Teknoloji Labaratuvar Uygulamaları 8.Sınıf, 1. Baskı, Pegem Akademi, Ankara.

Damlı, V. (2011). Kavramsal Değiş̧im Yaklaşımına Dayalı Web Tabanlı Etkileşimli Öğretimin Üniversite Öğrencilerinin Isı ve Sıcaklık Konusundaki Kavram Yanılgılarını Gidermeye Etkisi, Yayımlanmamış Yüksek Lisans Tezi, Gazi Üniversitesi Eğitim Bilimleri Enstitüsü, Ankara.

Demirci, M. P ve Sarıkaya, M. (2004). Sınıf Öğretmeni Adaylarının Isı ve Sıcaklık Konusundaki Kavram Yanılgıları ve Yanılgıların Giderilmesinde Yapısalcı Kuramın Etkisi, XIII. Ulusal Eğitim Bilimleri Kurultayı, 6-9 Temmuz 2004, Malatya, İnönü Üniversitesi Eğitim Fakültesi.

Demirci, M.P. (2003). Sinıf Öğretmeni Adaylarının Isı ve Sıcaklık Konusundaki Kavram Yanılgıları ve Bu Yanılgıların İyileștirilmesinde Yapısalcı Kuramın Etkisi, Yayımlanmamış Yüksek Lisans Tezi, Gazi Üniversitesi Eğitim Bilimleri Enstitüsü, Ankara.

Doris, E. (1991). Doing What Scientist Do. Children Learn To Investigate Their World, Heinemann Educational Books, Portsmouth.

Duban, N. (2008). İlköğretim Fen Öğretiminde Niçin Sorgulamaya Dayalı Öğrenme? (ietc2008.home.anadolu.edu.tr/ietc2008/155.doc), (Erişim Tarihi: 09 Mayıs 2016).

Erickson, G. L. (1979). Children's conceptions of heat and temperature, Science Education, 63(2), 221-230.

Eryılmaz, A. ve Sürmeli, E. (2002). Üç-Aşamalı Sorularla Öğrencilerin Isı ve Sıcaklık Konularındaki Kavram Yanılgılarının Ölçülmesi, V. Ulusal Fen Bilimleri ve Matematik Eğitimi Kongresi, 16-18 Eylül 2002, 
Ankara, Cilt:1,110 Online erişim www.metu.edu.tr/ eryilmaz/TamUcBaglant.pdf Erișim 21.12.2014.

Gönen, S., ve Akgün, A., (2005). Isı ve sıcaklık kavramları arasındaki ilişki ile ilgili olarak geliştirilen çalışma yaprağının uygulanabilirliğinin incelenmesi. Elektronik Sosyal Bilimler Dergisi, 3 (11), 92106.

Güler, N. (2005). Ortaöğretimde Isı, Sicaklık, Genleșme ve Elektrik Akımı Konularının Deney Yöntemi İle Anlatımının Kavram Yanılgılarını Gidermeye Etkisinin Araștırılması, Yayımlanmamış Yüksek Lisans Tezi, Süleyman Demirel Üniversitesi, Fen Bilimleri Enstitüsü: Isparta.

Gümüş, S., Öner, F., Kara, M., Orbay, M. , ve Yaman, S., (2003). Isı ve Sıcaklı Üzerine Kavram Yanılgıları, Milli Ĕgitim Dergisi, sayı:157.

Gürbüz, F. (2008). İlköğretim 6. Sinıf Öğrencilerinin Isı ve Sicaklık Konusundaki Kavram Yanılgılarının Düzeltilmesinde Kavramsal Değişim Metinlerinin Etkisinin Araștırılması. Yayımlanmamış Yüksek Lisans Tezi, Atatürk Üniversitesi, Fen Bilimleri Enstitüsü: Erzurum.

Gürdal-Kazancıoğlu, H. (2008). İlköğretim 5. Sınıf Fen ve Teknoloji Dersi, Maddenin Değișimi ve Tanınması Ünitesinde Öğrencilerde Oluşan Kavram Yanılgılarının Tespitinde İki Aşamalı Soruların Kullanılabilirliği Üzerine Bir Araştırma, Yayımlanmamış Yüksek Lisans Tezi, Celal Bayar Üniversitesi, Sosyal Bilimler Enstitüsü; Manisa.

Halliday, D. ve Resnick, R. (1997). Fiziğin Temelleri I, (Çev. Yalçın, C.) Arkadaş Yayınevi, Ankara.

Harlen, W. (2014). Helping children's development of inquiry skills. Inquiry in Primary Science Education (IPSE), 1, 5-19.

Harrison, A. G., Grayson, D. J. ve Treagust, D. F. (1999). Investigating a grade 11 student's evolving conceptions of heat and temperature, Journal of Research in Science Teaching, 36(1), 55-87.

İnal, A. (2003). Lise 1. Sinıftaki Öğrencilerin Isı ve Sicaklık Konusundaki Yanlış Kavramlarının Belirlenmesi ve Yapılandırmacı Yaklaşımın Yanlış Kavramların Giderilmesi Üzerindeki Etkisi, Yayımlanmamış Yüksek Lisans Tezi, Gazi Üniversitesi, Eğitim Bilimleri Enstitüsü: Ankara.

Jara-Guerrero S. (1993). Misconceptions on heat and temperature in the proceedings of the Third International Seminar on Misconceptions and Educational Strategies in Science and Mathematics, Misconceptions Trust: Ithaca, NY.

Jones, J.B. ve Dugan, R. E. (2003). Mühendislik Termodinamiği, (Çev.Atılgan, H.) 1. Baskı, Beta Yayıncılık, Kirklareli.

Jones, M.G., Childers, G., Emig, B., Chevrier, J., Tan, H., Stevens, V. ve List, J. (2014). The efficacy of haptic simulations to teach students with visual impairments about temperature and pressure, Journal of Visual Impairment\&Blindness, January-February, 55-61.

Kalem, R., ve Çallıca, H. (2001). Orta-2, lise-1 ve üniversite-1.sınıf öğrencilerinin ısı ve sıcaklık konusu ile ilgili kavram yanılgılarının incelenmesi. Fen Bilimleri Eğitimi Sempozyumu, Maltepe Üniversitesi, İstanbul, 260-265.

Kaptan, F., ve Korkmaz, H. (2001). İlköğretimde Fen Bilgisi Öğretimi. İlköğretimde Etkili Öğretme ve Öğrenme Öğretmen El Kitabı Modül 7, MEB, Ankara.

Karakuyu, Y. (2006). Lise ve Dengi Okul Öğrencilerinin Isı ve Sicaklık Öğreniminde Karşıllaştı̆̆ı Kavram Yanılgıları, Yayınlanmamış Doktora Tezi, Süleyman Demirel Üniversitesi, Fen Bilimleri Enstitüsü: Isparta.

Karakuyu, Y., Uzunkavak, M., Tortop, H.S., Bezir, N.Ç. ve Özek, N. (2009). Sandıklı - Çevresi Lise ve Dengi Okul Öğrencilerinin Isı ve Sıcaklık İle İlgili Kavram Yanılgılarının Belirlenmesi, Afyon Kocatepe Üniversitesi Fen Bilimleri Dergisi, 8(1), 149-162.

Karasar, N. (2003). Bilimsel Araştırma Yöntemi, Ankara: Nobel Yayın Dağıtım.

Keser, A. (2007). Afyonkarahisar Il Merkezindeki 9.Sınıf Öğrencilerinin Isı ve Sıcaklık Konusundaki Kavram Yanılgıları, Yayımlanmamış Yüksek Lisans Tezi, Afyon Kocatepe Üniversitesi, Fen Bilimleri Enstitüsü; Afyonkarahisar.

Kesidou, S ve Duit, R. (1993). Student' conceptions of the second law of thermodynamics- An interpretative study, Journal of Research in ScienceTeaching, 30(1): 85-106.

Keskin Özer, M.,Kaşker Özkan, Ș. ve Uysal, M. (2014). İlköğretim Fen ve Teknoloji Ders ve Öğrenci Çalışma Kitabı 41. Kitap, (Edit. Suzan, M.), Doku Yayınclık, Ankara.

Kırtak, V. N. (2010). Fizik, Kimya ve Biyoloji Öğretmen Adaylarının Termodinamik Yasalarını Günlük Hayatla ve Çevre Sorunları İle İlişkilendirme Düzeyleri, Yüksek Lisans Tezi, Balıkesir Üniversitesi, Fen Bilimleri Enstitüsü; Balıkesir.

Kocakülah, M., ve Kocakülah, A. (2002). Orta Öğretim Öğrencilerinin Isı ve Sıcaklıkla İlgili Kavramsal Yapıları, V. Ulusal Fen Bilimleri ve Matematik Eğitimi Kongresi, 16-18 Eylül 2002, Ankara, 1. Cilt: 124. Online erişim http://old.fedu.metu.edu.tr/ufbmek-5/b kitabi/PDF/Fizik/Bildiri/t124DD.pdf Erișim 21.12.2014. 
Korkmaz, H. ve Kaptan, F. (2002). Fen Öğretiminde Öğrencilerin Gelişimini değerlendirmek için Portfolyo kullanımı üzerine bir inceleme, Hacettepe Üniveristesi Eğitim Fakültesi Dergisi, 23, 167-176.

Kurnaz, M.A., Değirmenci, A., Kalyoncu, A., Pektaş, E., Bayraktar, G., Aydın, U. ve Moradaoğlu, Y. (2014). Ortaöğretim Fizik 11 Ders Kitabı, 5. Baskı (Edit. Çepni, S.), MEB, Ankara.

Laçin- Şimşek, C. ve Tezcan, R. (2008). Çocukların Fen Kavramlarıyla İlgili Düşüncelerinin Gelişimini Etkileyen Faktörler, Illköğretim Online, 7(3), 569-577.

Lederman, N. G. (2006). Syntax of nature of science within inquiry and science instruction. In L. B. Flick \& N. G. Lederman (Eds.), Scientific Inquiry and Nature of Science (pp. 1-14). Nederlands: Springer.

Magnussen, L., Ishida, D., \& Itano, J. (2000). The impact of the use of inquiry-based learning as a teaching methodology on the development of critical thinking. Journal of Nursing Education, 39, (8), 360364.

McCue, G., Gossner, S.D., Loomis, H. B., McDonald, J. ve Osmundsen, S. (1970). Enerji, Time Inc, İstanbul.

MEB, (2014a). Ortaokul Fen Bilimleri 5. Sinıf 1.Kitap, 2. Baskı, MEB, Ankara.

MEB, (2014b). Ortaöğretim Fizik 9. Sinıf, 1. Baskı, MEB, Ankara.

Mert S. (2002). Isı ve Sicaklık Konusunun İlköğretim Fen Bilgisi Derslerindeki Anlaşılma Düzeyinin ve Oluşan Kavram Yanılgılarının Belirlenmesi, Yayımlanmamış Yüksek Lisans Tezi, Gazi Üniversitesi, Eğitim Bilimleri Enstitüsü; Ankara.

Oguz-Unver, A., \& Arabacioglu, S. (2014). A comparison of inquiry-based learning (IBL), problem-based learning (PBL) and project-based learning (PjBL) in science education. Academia Journal of Educational Research, 2(7), 120-128.

Oguz-Ünver, A., (2015). Bilimin Doğası ve Bilimsel Sorgulama İlişsisi, Bilimin Doğası Gelişimi ve Öğretimi (ed. Doç. Dr. Nilgün Yenice), Ankara, Anı Yayıncllık, 217-256. ISBN:978-605-170-054-0.

Ongun, E. (2006). Üniversite Öğrencilerin Isı ve Sicaklık Konusundaki Kavram Yanılgıları Ile Motivasyon ve Bilișsel Stilleri Arasındaki İlişski, Yayımlanmamış Yüksek Lisans Tezi, Abant İzzet Baysal Üniversitesi, Sosyal Bilimleri Enstitüsü: Bolu.

Öcal, C. (2014). Ortaokul Fen Bilimleri 6. Sinıf, (Edit. Özdoğan, H.), Fenbil Yayıncllık, İstanbul.

Öner-Sünkür, M., İlhan, M. ve Sünkür, M. (2013). Sinıf Öğretmenliği Öğrencilerinin Isı ve Sıcaklık Konularındaki Kavram Yanılgılarının Giderilmesine Tahmin Et-Gözle-Açıkla (TGA) Yönteminin Etkisi, JASSS, 6(4), 519-534.

Radtka, C. (2013). Temperature in ScienceTextbooks: ChangesandTrends in Cross-NationalPerspective (1950-2000), Sci\&Educ, Vol:22, 847-866. DOI:10.1007/s11191-012-9533-x.

Sarı-Ay, Ö. (2011). Illköğretim 8. Sinıf Fen ve Teknoloji Dersi 'Maddenin Halleri ve Isı' Ünitesinde Belirlenen Kavram Yanılgılarının Giderilmesinde Kavramsal Değişim Metinleri Kullanımının Etkisi ve Öğrenci Görüşleri, Yayınlanmamış Yüksek Lisans Tezi, Hacettepe Üniversitesi, Sosyal Bilimler Enstitüsü: Ankara.

Sears, F. W ve Salinger, G. L. (2002). Termodinamik Kinetik Kuram ve İstatistik Termodinamik, 1. Baskl, (Çev. Ünal, N.), Literatür Yayıncılık, İstanbul.

Serway, R. A. (1995). Serway Fen ve Mühendislik için Fizik, (Çev. Edit. Çolakoğlu, K.), 3. Baskı, Palme Yayıncllık, Ankara.

Spencer, J.N., Farrel, J.J., \& Mogg, R. S. (1999). A guided inquiry general chemistry course. Journal of Chemistry Education, 76, 543-547.

Taşlıdere, E., Korur, F. ve Eryılmaz, A (2012). Kavram Yanılgılarının Üç Aşamalı Sorularala Farklı Bir Şekilde Değerlendirilmesi, X. Ulusal Fen Bilimleri ve Matematik Eğitimi Kongresi, 27-30 Haziran 2012, Online erişim http://kongre.nigde.edu.tr/xufbmek/dosyalar/tam_metin/pdf/23122905 2012-14 14 13.pdf Erişim: 21.12.2014.

TDK, Türk Dil Kurumu, Erişim tarihi 14 Temmuz 2016, http://www.tdk.gov.tr/index.php?option=com bilimsanat\&arama=kelime\&guid=TDK.GTS.57879 $\underline{44293 \mathrm{db} 82.31613116}$

Thomaz, M. F., Malaquias, I. M., Valente, M. C., ve Antunes, M. J., (1995). An attempt to overcome alternative conceptions related to heat and temperature, Physics Education, 30, 19-26.

Tiberghien, A. (2000). Heat \& Temperature, Children's Ideas in Science, 52-84.

Turgut, Ü. ve Gürbüz, F. (2011). Isı ve Sıcaklık Konusunda 5e Modeliyle Öğretimin Öğrencilerdeki Kavramsal Değișime ve Onların Tutumlarına Etkisi, International Online Journal of Educational Sciences, 3(2): 679-706.

Uzoğlu, M. ve Gürbüz, F. (2013). Fen ve Teknoloji Öğretmen Adaylarının Isı ve Sıcaklık Konusundaki Kavram Yanılgılarının Belirlenmesinde Öğrenme Amaçlı Mektup Yazma Aktivitesinin Kullanilmasi, JASSS, 6(4), 501-517.

Ünver, E. (2014). İlköğretim Fen ve Teknoloji 8 Ders Kitabı, Dikey Yayıncılık, Ankara. 
Yağbasan, R. ve Gülçiçek, Ç. (2003) Fen Öğretiminde Kavram Yanılgllarının Karakteristiklerinin Tanımlanması, Pamukkale Üniversitesi Eğitim Fakültesi Dergisi, 1(13): 102-120.

Yavuz, S. ve Büyükekşi, C. (2011). Kavram Karikatürlerinin Isı ve Sıcaklık Öğretiminde Kullanılması, Karaelmas Fen ve Mühendislik Dergisi, 1(2), 25-30.

Yeşilyurt, M. (2006). Lise Öğrencilerinin Isı Ve Sıcaklık Kavramları İle İlgili Düşünceleri, International Journal of Environmental and Science Education, 1(1), 1-24.

Ylldırım, A. ve Şimşek, H. (2011) Sosyal Bilimlerde Bilimsel Araştırma Yöntemleri, Seçkin Yayıncılık, Ankara.

Yılmaz, T. (2005). Lise 2. Sinıftaki Öğrencilerin Isı ve Sıcaklık Konusundaki Yanlış Kavramlarının Belirlenmesi ve Yapılandırmacı Yaklaşımın Yanlış Kavramların Giderilmesi Üzerine Etkisi. Yayınlanmamış Yüksek Lisans Tezi, Gazi Üniversitesi, Eğitim Bilimleri Enstitüsü, Ankara.

Young, H.D., Freedman, R.A. ve Ford, A.L. (2008). Sears ve Zemansky'ın Üniversite Fiziğii, (Çev. Ünlü, H.), 12. Baskı, Pearson Education Yayıncllık, İstanbul.

Yumuşak, A.,Türkoğuz, S., Aycan, Ș. ve Aycan, N. (2004). Bazı Temel Fen Kavramlarının Öğretimindeki Yetersizlikler ve Nedenleri (Manisa Örneği). Çă̆daş Ĕ̆itim Dergisi, 312, 38-46.

Yürümezoğlu, K. ve Oğuz, A. (2007). Bilim Eğitiminde Gözlemin Önceliği: Duyularımla Gözlemliyorum. 1. Ulusal İlköğretim Kongresi, Hacettepe Üniversitesi, Ankara.

Yürümezoğlu, K. ve Oğuz, A. (2009). Hipotez Test Sürecinde Çocukların ve Yetişkinlerin Bilişsel Düşünme Eğilimleri. Hacettepe Üniversitesi Eğitim Fakültesi Dergisi, 36, 340-350. 
Ad Soyad:

\section{Ek 1:Çalışma Yaprağı}

Bölüm / Sınıf:

..6!l

Havanın sıcaklığını nasıl ölçtüğünüzü ve kaç ölçtüğünüzü lütfen kaydediniz?

Ölçüm sonucunuza güveniyor musunuz?

Evet güveniyorum. Çünkü.....

Hayır güvenmiyorum. Çünkü.......

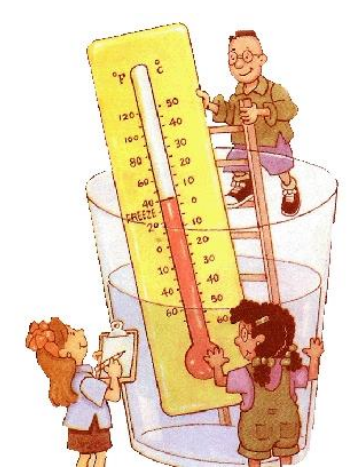


Ek 2: Termometre Değerlendirme Formu

\begin{tabular}{|c|c|c|}
\hline \multicolumn{3}{|c|}{ Termometre gerçeğe ne kadar yakın? } \\
\hline \multicolumn{3}{|c|}{ Termometrenin ölçüm aralığı ne? } \\
\hline \multicolumn{3}{|l|}{ Termometre hangi sıcaklık biriminde ölçüm yapıyor? } \\
\hline Termometre sürekli ölçüm yapabiliyor mu? & Evet & Hayır \\
\hline Termometrenin ölçme süresi kısa mı uzun mu? & Kisa & Uzun \\
\hline \multicolumn{3}{|l|}{ Termometrenin hassasiyeti ve hata payı nedir? } \\
\hline \multicolumn{3}{|l|}{ Termometrenin doğruluğu nedir? } \\
\hline \multicolumn{3}{|c|}{ Termometrenin tutarlılı̆̆ı nasıldır? } \\
\hline \multicolumn{3}{|c|}{ Termometre hangi ilkeye göre tasarlanmıș? } \\
\hline \multicolumn{3}{|l|}{ Sıvıların hacim değișimi } \\
\hline \multicolumn{3}{|l|}{ Katıların uzunluk değișimi } \\
\hline \multicolumn{3}{|l|}{ Sabit hacimdeki bir gazın basınç değișimi } \\
\hline \multicolumn{3}{|l|}{ Sabit basınçtaki bir gazın hacim değișimi } \\
\hline \multicolumn{3}{|l|}{ Bir iletkenin elektrik direncinin değişimi } \\
\hline \multicolumn{3}{|l|}{ Çok sıcak cisimlerin renk değişimi } \\
\hline \multirow{2}{*}{\multicolumn{3}{|c|}{ Termometre hangi maddelerin sıcaklıŏını ölcüvor? }} \\
\hline & & \\
\hline \multicolumn{3}{|l|}{ Katıların sıcaklığı } \\
\hline \multicolumn{3}{|l|}{ Siviların sicaklığı } \\
\hline \multicolumn{3}{|l|}{ Gazların sıcaklığı } \\
\hline \multicolumn{3}{|l|}{ Diğer } \\
\hline \multicolumn{3}{|c|}{ Termometrenin tasarımı ve işlevselliği nasıl? } \\
\hline Termometrenin maliyeti düșük mü? & Evet & Hayır \\
\hline Termometre kolay kurulabilir mi? & Evet & Hayır \\
\hline Termometre kolay taşınabilir mi? & Evet & Hayır \\
\hline Termometreyi bağımsız bir kullanıı kullanabilir mi? & Evet & Hayır \\
\hline Termometre ilgi çekici mi? & Evet & Hayır \\
\hline Termometrenin ilgiyi sürdürebilir mi? & Evet & Hayır \\
\hline Termometre sağlam ve dayanıklı mı? & Evet & Hayır \\
\hline Termometrenin kullanımı kolay mı? & Evet & Hayır \\
\hline Termometrenin depolanması kolay mı? & Evet & Hayır \\
\hline Termometrenin raf ömrü uzun mu? & Evet & Hayır \\
\hline
\end{tabular}

